\title{
European Guidelines for Obesity Management in Adults with a Very Low-Calorie Ketogenic Diet: A Systematic Review and Meta-Analysis
}

\author{
Giovanna Muscogiuria, b Marwan El Ghoch ${ }^{c}$ Annamaria Colao ${ }^{a, b}$ \\ Maria Hassapidou ${ }^{d}$ Volkan Yumuk ${ }^{\mathrm{e}}$ Luca Busetto $^{\mathrm{f}}$ Obesity Management \\ Task Force (OMTF) of the European Association for the Study of Obesity (EASO) \\ a Dipartimento di Medicina Clinica e Chirurgia, Sezione di Endocrinologia, Università Federico Il di Napoli, Naples, \\ Italy; ${ }^{b}$ Cattedra Unesco - Educazione alla salute e allo sviluppo sostenibile, Università Federico II, Naples, Italy; \\ 'Department of Nutrition and Dietetics, Faculty of Health Sciences, Beirut Arab University, Beirut, Lebanon; \\ ${ }^{\mathrm{d}}$ Department of Nutritional Sciences and Dietetics, International Hellenic University, Thessaloniki, Greece; \\ e Division of Endocrinology, Metabolism, and Diabetes, Istanbul University Cerrahpaşa Medical Faculty, Istanbul,

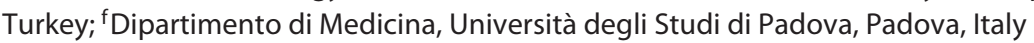

\section{Keywords}

Body weight - Body composition - Clinical outcomes .

Glycemic profile · Lipid profile · Obesity · Weight loss · Very

low-calorie ketogenic diet · Guidelines · Body mass index

\begin{abstract}
Background: The very low-calorie ketogenic diet (VLCKD) has been recently proposed as an appealing nutritional strategy for obesity management. The VLCKD is characterized by a low carbohydrate content $(<50 \mathrm{~g} /$ day $), 1-1.5 \mathrm{~g}$ of protein $/ \mathrm{kg}$ of ideal body weight, $15-30 \mathrm{~g}$ of fat/day, and a daily intake of about 500-800 calories. Objectives: The aim of the current document is to suggest a common protocol for VLCKD and to summarize the existing literature on its efficacy in weight management and weight-related comorbidities, as well as the possible side effects. Methods: This document has been prepared in adherence with Preferred Reporting Items for Systematic Review and Meta-Analyses (PRISMA) guidelines. Literature searches, study selection, methodology development, and quality appraisal were performed independently by 2 authors and the data were collated by means of a meta-analysis and narrative synthesis.
\end{abstract}

Results: Of the 645 articles retrieved, 15 studies met the inclusion criteria and were reviewed, revealing 4 main findings. First, the VLCKD was shown to result in a significant weight loss in the short, intermediate, and long terms and improvement in body composition parameters as well as glycemic and lipid profiles. Second, when compared with other weight loss interventions of the same duration, the VLCKD showed a major effect on reduction of body weight, fat mass, waist circumference, total cholesterol and triglyceridemia as well as improved insulin resistance. Third, although the VLCKD also resulted in a significant reduction of glycemia, HbA1c, and LDL cholesterol, these changes were similar to those obtained with other weight loss interventions. Finally, the VLCKD can be considered a safe nutritional approach under a health professional's supervision since the most common side effects are usually clinically mild and easily to manage and recovery is often spontaneous. Conclusions: The VLCKD can be recommended as an effective dietary treatment for individuals with obesity after considering potential contra-indications and keeping in mind that

G.M. and M.E.G. contributed equally to the preparation and writing of this document.
C 2021 The Author(s)

Published by S. Karger AG, Basel

This is an Open Access article licensed under the Creative Commons Attribution-NonCommercial-4.0 International License (CC BY-NC) (http://www.karger.com/Services/OpenAccessLicense), applicable to the online version of the article only. Usage and distribution for commercial purposes requires written permission.
Correspondence to:

Giovanna Muscogiuri, giovanna.muscogiuri@gmail.com 
any dietary treatment has to be personalized. Prospero Registry: The assessment of the efficacy of VLCKD on body weight, body composition, glycemic and lipid parameters in overweight and obese subjects: a meta-analysis (CRD42020205189).

(c) 2021 The Author(s)

Published by S. Karger AG, Basel

\section{Introduction}

Obesity is becoming a plague in countries all around the world, affecting over 200 million men and nearly 300 million women [1]. Beyond the body weight excess, obesity has been defined as "the silent killer"; indeed, it significantly increases the risk and contributes to the development of several diseases such as cardiovascular diseases, type 2 diabetes, dyslipidemia, arthropathy, some neoplasms, and infertility $[2,3]$.

Several strategies are currently used for weight management in obesity, with the first attempt to lose weight being focused on lifestyle changes based on physical activity and dietary recommendations. Usually, the most recommended nutritional pattern is characterized by an increase in complex/raw carbohydrates along with a reduction in fat intake aiming to reduce energy intake and increase energy expenditure through physical activity [4]. Lifestyle modification programs are not always successful, especially in patients with severe obesity. On the other hand, the use of antiobesity drugs is currently limited by nontrivial costs, potential side effects, and contraindications that cannot make them suitable for all subjects with obesity $[5,6]$. Finally, bariatric surgery is another tool used for weight loss, mostly indicated for individuals with severe obesity (i.e., BMI $=40$ or 35 with obesity-associated comorbidities). Despite its effectiveness for remission of type 2 diabetes, bariatric surgery can lead to several irreversible complications related to surgical procedures [7] and its availability is limited.

Recently, very low-carbohydrate ketogenic diets (VLCKD) have been proposed as an appealing nutritional strategy for obesity management [8]. VLCKD are characterized by a low carbohydrate content $(<50 \mathrm{~g} /$ day $)$, $1-1.5 \mathrm{~g}$ of protein $/ \mathrm{kg}$ of ideal body weight, $15-30 \mathrm{~g}$ of fat/ day, and about $500-800 \mathrm{kcal} /$ day [8]. The reduction of carbohydrate intake under the above reported threshold leads to ketone synthesis [9]. Ketone bodies are then utilized as fuel by several extrahepatic tissues such as the central nervous system, skeletal muscle, and the heart. To favor the patients' compliance, VLCKD are often delivered through meal replacements mimicking a natural diet. Among the beneficial effects, VLCKD have been reported to induce more weight loss than a standard lowcalorie diet after 1 and 2 years of follow-up [10], to preserve muscle mass, muscle strength, and resting metabolic rate [11].

In view of these considerations, the 3 main aims of the current document were to: (1) describe a typical VLCKD protocol highlighting its indications and contraindications; (2) conduct a systematic review and meta-analysis on the efficacy of this protocol in terms of clinical outcomes (i.e., in the short and long term), i.e., weight loss and maintenance, and changes in body composition parameters and glycemic and lipid profiles; and finally (3) summarize the side effects (i.e., common and rare) of this dietary treatment as well as its medical management. A practical recommendation for the application of VLCKD in obesity management is therefore formulated.

\section{VLCKD Protocol}

The VLCKD is a nutritional protocol characterized by a reduction of daily carbohydrate intake, usually lower than $30 \mathrm{~g} /$ day $(\simeq 13 \%$ of the total energy intake), a relative increase in fat $(\sim 44 \%)$ and protein $(\sim 43 \%)$ percentages, and a total daily energy intake $<800 \mathrm{kcal}[12]$. The VLCKD protocol includes high-biological-value protein (coming from milk, peas, whey, and soy) artificial meals, and natural foods. Each artificial meal typically includes $18 \mathrm{~g}$ of protein, $4 \mathrm{~g}$ of carbohydrate, and $3 \mathrm{~g}$ of fat (mainly higholeic vegetable oils) and provides approximately 100-150 $\mathrm{kcal}$. This protocol is characterized by the following 3 stages: active, reeducation, and maintenance (Fig. 1).

\section{Active Stage}

The active stage is a very low-calorie diet (600-800 $\mathrm{kcal} /$ day) characterized by low amounts of carbohydrates $(<50 \mathrm{~g}$ daily from vegetables) and lipids (only $10 \mathrm{~g}$ of olive oil per day). The amount of high-biological-value proteins ranged between 0.8 and $1.2 \mathrm{~g} / \mathrm{kg}$ of ideal body weight to preserve lean mass and meet the minimal daily body requirements. This stage is further divided in 3 ketogenic phases; in phase 1, the patients eat high-biological-value protein meals with vegetables with a low glycemic index 4-5 times a day. In phase 2 , one of the protein artificial servings is replaced by a natural protein meal such as meat/egg/fish either at lunch or at dinner. In phase 3, a second serving of the natural protein low in fat can replace the second artificial protein serving. Supplementations with micronutrients (vitamins and minerals, such as $\mathrm{K}$, 
Fig. 1. Scheme of the stages of VLCKD pro-

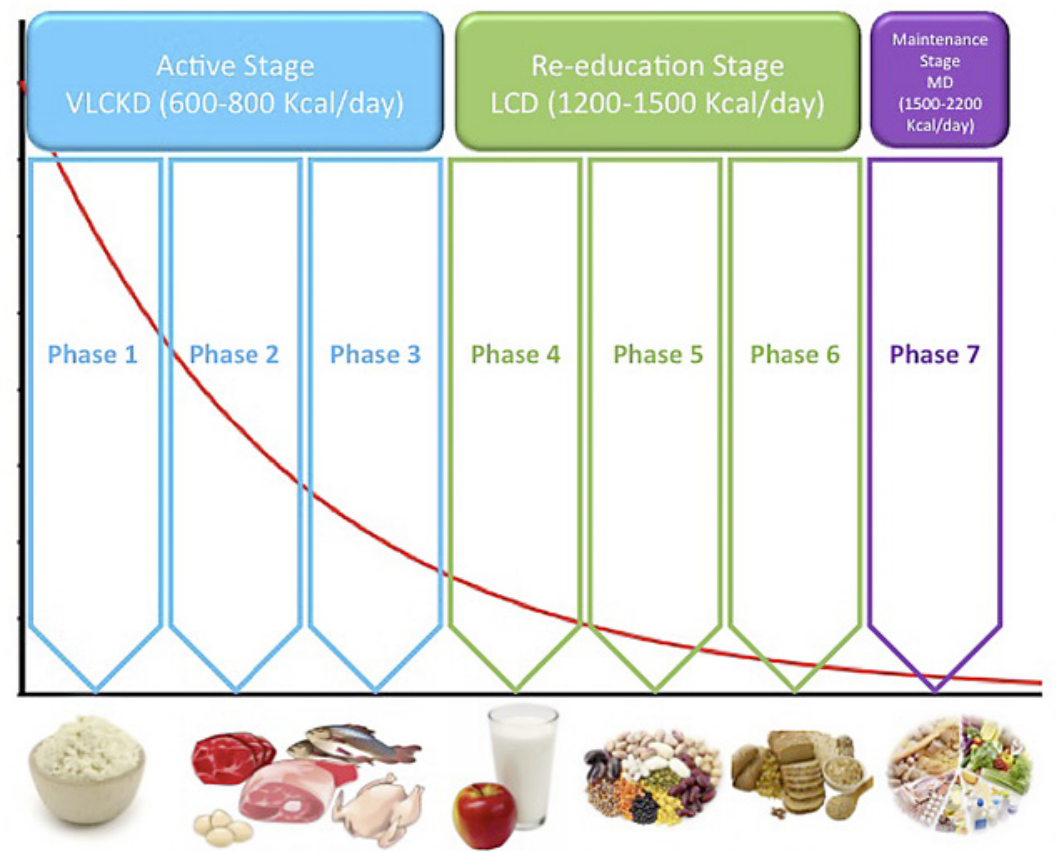
tocol.

$\mathrm{Na}, \mathrm{Mg}, \mathrm{Ca}$, and omega-3 fatty acids) are suggested at this stage. The active stage usually lasts $8-12$ weeks, until the subjects lose most of the weight loss target (about 80\%).

In the literature, it has also been reported that the active stage protocol could be reached providing half of the amount of daily protein using synthetic amino acid supplementation containing whey protein $(13.42 / \mathrm{bag})$, carbohydrate $(0.03 / \mathrm{bag})$, fat $(0.15 / \mathrm{bag})$, isoleucine $(0.31 /$ bag), ornithine a-ketoglutarate $(0.25 / \mathrm{bag})$, L-citrulline $(0.25 / \mathrm{bag})$, taurine, $(0.25 / \mathrm{bag})$, L-tryptophan $(0.05 / \mathrm{bag})$, and potassium citrate $(0.45 / \mathrm{bag})$, for a total of $64 \mathrm{kcal}(268$ $\mathrm{KJ})$ which are dissolved in water. This drink is taken at breakfast and lunch or dinner [13].

\section{Reeducation Stage}

After the active stage, the patients will progressively reintroduce different food groups and in the meantime take part in a program of nutritional reeducation to keep long-term weight loss. Carbohydrates are gradually reintroduced according to the following order: foods with the lowest glycemic index (fruit and dairy products - phase 4), followed by foods with moderate (legumes - phase 5), and a high glycemic index (bread, pasta, and cereals phase 6). The daily calorie intake in the reintroduction stage (phases 4-6) varies between 800 and 1,500 kcal/day.

\section{Maintenance Stage}

After the reintroduction stage, there is a maintenance stage which includes a nutritional program that ranges from 1500 to $2000 \mathrm{kcal} /$ day, depending on the individual, and that is balanced by macronutrients and micronutrients viewpoints. The main purpose of this stage is the maintenance of long-term weight loss and to promote a healthy lifestyle.

\section{Efficacy of VLCKD in Terms of Weight Loss, and Changes in Body Composition Parameters and Glycemic and Lipid Profiles: Systematic Review and Meta-Analysis}

\section{PICO Statements}

We set out to conduct a systematic review on the topic in accordance with the PICO process [14], as detailed below:

$P$ (population): adult participants (age $\geq 18$ years) in the overweight or obesity categories however defined (i.e., BMI, body fat, waist circumference [WC], etc.) with or without comorbidities.

I (intervention): short- or long-term weight loss followed or not by a period of weight maintenance. 
C (comparison): weight loss programs involving a VLCKD as a treatment for obesity/overweight, compared to any other diet as defined by the authors (whenever available).

$\mathrm{O}$ (outcome): changes in the following outcomes: body weight status, body composition, and glycemic and lipid profiles.

Body weight status (primary outcome) comprises: mean weight loss expressed as weight $(\mathrm{kg})$ and BMI before and after VLCKD at 1,2, 4-6, 12 and 24 months of follow-up, and comparison of mean weight loss between VLCKD and any other intervention in terms of weight $(\mathrm{kg})$ and BMI changes.

Body composition (secondary outcome) comprises: WC (mean difference in $\mathrm{cm}$ between baseline and the last available follow-up in the VLCKD group), and comparison of changes in WC in $\mathrm{cm}$ between VLCKD and any other intervention.

Fat mass (FM) comprises: the mean difference (in $\mathrm{kg}$ ) between baseline and the last available follow-up in the VLCKD group, and comparison of changes in FM (in kg) between VLCKD and any other intervention.

Fat-free mass (FFM) comprises: the mean difference (in $\mathrm{kg}$ ) between baseline and the last available follow-up in the VLCKD group, and comparison of changes in FFM (in kg) between VLCKD and any other intervention.

Biochemical assessment comprises the glycemic profile, which includes: fasting blood glucose (FBG) (mean difference expressed in $\mathrm{mg} / \mathrm{dL}$ between baseline and the last available follow-up in the VLCKD group, and comparison of changes in FBG in $\mathrm{mg} / \mathrm{dL}$ between VLCKD and any other intervention), the Homeostatic Model Assessment for Insulin Resistance (HOMA index) (mean difference in HOMA index between baseline and the last available follow-up in the VLCKD group, and comparison of changes in HOMA index between VLCKD and any other intervention), and glycated hemoglobin (HbAlc) (mean difference in $\mathrm{HbAlc}$ expressed in \% between baseline and the last available follow-up in the VLCKD group, and comparison of changes in $\mathrm{HbA} 1 \mathrm{c}$ between VLCKD and any other intervention).

Biochemical assessment also comprises the lipid profile, which includes: total cholesterol (mean difference in total cholesterol expressed in $\mathrm{mg} / \mathrm{dL}$ between baseline and the last available follow-up in the VLCKD group, and comparison of changes in total cholesterol between VLCKD and any other intervention), low-density lipoprotein (LDL) cholesterol (mean difference in LDL expressed in $\mathrm{mg} / \mathrm{dL}$ between baseline and the last available follow-up in the VLCKD group, and comparison of changes in LDL between VLCKD and any other intervention), high-density lipoprotein (HDL) cholesterol (mean difference in HDL expressed in $\mathrm{mg} / \mathrm{dL}$ between baseline and the last available follow-up in the VLCKD group, and comparison of changes in LDL between VLCKD and any other intervention), and triglycerides (TG) (mean difference in TG expressed in $\mathrm{mg} / \mathrm{dL}$ between baseline and the last available follow-up in the VLCKD group, and comparison of changes in TG between VLCKD and any other intervention).

\section{Methods}

The meta-analysis was presented in adherence with Preferred Reporting Items for Systematic Review and Meta-Analyses (PRISMA) guidelines for completion of this review [15]. PROSPERO registry (September 20, 2020): “The Assessment of the Efficacy of VLCKD on Body Weight, Body Composition, Glycaemic and Lipid Parameters in Overweight and Obese Subjects: A Meta-Analysis" (CRD42020205189).

\section{Inclusion and Exclusion Criteria}

We includes all studies dealing with VLCKD and evaluating changes in weight status (expressed in any way) and changes in any weight-related clinical outcome before and after VLCKD, provided that they met the following criteria: (1) studies written in English; (2) original articles or studies with a longitudinal design; and (3) prospective or retrospective observational (analytical or descriptive), experimental, or quasi-experimental controlled studies. No reviews, cross-sectional, noncontrolled, or nonoriginal articles (i.e., case reports, editorials, letters to the editor, and book chapters) were included.

Considering that there is no complete agreement or set definition among clinicians and researchers regarding the macronutrients in VLCKD (i.e., carbohydrate, protein, and fat thresholds), for the purposes of this review we adopted the following [8]: total daily calories, $\leq 800 \mathrm{kcal}$; carbohydrates, $30-50 \mathrm{~g} /$ day (13-25\% of the total calories); protein, $0.8-1.2 \mathrm{~g} /$ day for an ideal body weight ( $\sim 40-45 \%$ of the total calories); and fat ( $40-45 \%$ of the total calories).

\section{Information Source and Search Strategy}

The literature search was performed independently and in duplicate by 2 authors. Databases were systematically screened using the following $\mathrm{MeSH}$ terms combinations as follows: 1 obesity, 2 overweight, 3 very low-calorie ketogenic diet, 4 VLCKD, 5 VLKD, 6 weight loss, 7 weight reduction, 8 weight maintenance, 9 clinical outcomes, 10 body composition, 11 fat mass, 12 body fat, 13 fatfree mass, 14 lean body mass, 15 glycemic profile, 16 glycemia, 17 fasting blood glucose, $18 \mathrm{HbA} 1 \mathrm{c}, 19$ HOMA-IR index, 20 lipid profile cholesterol, 21 LDL cholesterol, $22 \mathrm{HDL}$ cholesterol, and 23 TG. The following combinations were also applied as search parameters: (1 OR 2) AND (3) AND (4 OR 5 OR 6) AND (7 OR 8 OR 9 OR 10 OR 10 OR 11 OR 12 OR 13 OR 14 OR 15 OR 16 OR 17 OR 18 OR 19 OR 20 OR 21 OR 22 OR 23). 
In addition, a manual search was carried out to retrieve other articles that were not identified via the initial search strategy. Publication date was not considered an exclusion criterion for the purposes of this review.

\section{Study Selection and Quality Assessment}

Two authors (G.M. and M.E.G.) independently screened the resulting articles for their methodology and appropriateness for inclusion. Noncontrolled observational studies were selected according to the National Institute for Health and Clinical Excellence (NICE) guideline checklist for quality appraisal [16]. For controlled observational studies, the appraisal was conducted according to the Newcastle-Ottawa Scale (NOS) [17], which relies on a 9-point system in which scores of 0-6 and 7-9 are considered poor and moderate to good quality, respectively. Scores of 4, 2, and 3, respectively, were assigned to the following criteria: selection of study groups, comparability of study groups, and assessment of outcomes and adequacy of follow-up criteria [18]. In randomized controlled trials, quality appraisal was conducted according to the Jadad scale [19], which relies on the following 3 items: randomization ( 2 points), blinding ( 2 points), and description of withdrawals or dropout (1 point), for a total of 5 possible points; $\geq 3$ points indicates a good-quality trial [20]. Moreover, randomized controlled trials were assessed using risk-of-bias criteria, although 10 criteria (i.e., randomization method, allocation sequence concealment, participant blinding, outcome assessor blinding, outcome measurement, interventionist training, withdrawal, intent-totreat analyses, clustering, and baseline characteristics) are generally used to assess the sufficiency of reporting. Studies were assigned a "yes" for each applicable criterion they fulfilled and a "no" for each criterion they did not fulfill. Studies containing insufficient information for judgement were indicated as "not reported," and any disagreement was documented and resolved by discussion [21]. Consensus discussion was used to resolve disagreements between reviewers.

\section{Data Collection Process and Data Items}

First, both the title and the abstract of each paper were assessed by 2 independent authors for language suitability and subject matter relevance, and then the selected studies were assessed for their appropriateness for inclusion and the quality of the methods. The following characteristics are reported in Table 1 for each study that passed these 2 rounds of screening: first author, year of publication, country of conduction, design, sample age, baseline weight, duration of follow-up, and outcome.

\section{Data Synthesis}

The studies that met the inclusion criteria are presented as a narrative synthesis. The effect size of interest was the raw mean difference in weight, BMI, WC, glycemic indicators, and blood lipid profile, reflecting a change from baseline and different intervals of VLCKD or differences from the control group. The mean difference was calculated as the difference between the reported means (equation 1):

$$
D=\overline{X_{2}}-\overline{X_{1}}
$$

The SD of the difference between means was calculated using the SEM for each reported mean (equation 2):

$$
S D=\sqrt{\frac{S_{1}^{2}}{n_{1}}+\frac{S_{2}^{2}}{n_{2}}}
$$

For reported means with a missing SD, the SD was imputed from other studies [22]. A meta-analysis was performed to calculate a weighted average of the overall mean differences from different studies included in the model. Assessment of heterogeneity was done using $I^{2}$ statistics as a measure of inconsistency to test that variation in effect estimates is only due to chance. Acceptable heterogeneity was determined at $I^{2}<60 \%$. In studies with acceptable heterogeneity, analysis of pooled effects was done using a fixed-effects model. In studies with heterogeneity above $60 \%$, a random-effects model was used [22]. A forest plot was used plotted to compare the change in outcomes of interest in response to VLCKD. Revman 5.3 was used to perform the meta-analysis and draw the forest plots [23]. For all statistical tests, $p<0.05$ was considered statistically significant.

\section{Results}

The initial search retrieved 645 papers, and 321 were immediately eliminated because they were considered duplicates; thus 324 screened reports remained. In the first round of screening (titles and abstracts), $252 \mathrm{pa}$ pers were excluded on the following grounds: language other than English, no bearing on overweight and obesity, and dealing with overweight and obesity but not clearly considering VLCKD. In the second round of screening of the remaining 72 articles, full-text papers were assessed for eligibility. A further 57 articles were excluded for: (1) being review articles (i.e., systematic or narrative) or consensus protocol studies; (2) dealing with diets similar to but not the same as VLCKD, such as very low-calorie diets (VLCD) and very low-carbohydrate diets (but not well identified in the abstract); and (3) VLCKD that did not satisfy our VLCKD protocol (Fig. 2).

In the end, 15 articles ( 7 noncontrolled, 2 controlled, and 6 randomized controlled studies) were available for systematic review, narrative, and meta-analysis. According to the NICE guidelines checklist, the noncontrolled studies $(n=7)$ were of a fair quality (mean score: 6.42 points; online suppl. Table 1; for all online suppl. material, see www.karger.com/doi/10.1159/000515381), while the NOS checklist indicated that the controlled studies $(n=2)$ were of a moderate quality (mean score: 5.50 points; online suppl. Table 2). Finally, the Jadad scale checklist indicated that the randomized controlled studies $(n=6)$ were of a high quality (mean score: 3.16 points; online suppl. Table 3), and the risk of bias was acceptable (online suppl. Table 4). Finally, the PRISMA checklist reported, item by item, the adherence to PRISMA guidelines for completion of this review (online suppl. Table 5). 
Table 1. Studies included in the systematic review

\begin{tabular}{|c|c|c|c|c|c|c|c|c|}
\hline First author & Year & Country & Design & Sample & $\begin{array}{l}\text { Mean age }( \pm S D) \text {, } \\
\text { years }\end{array}$ & Baseline weight status & $\begin{array}{l}\text { Follow-up } \\
\text { duration }\end{array}$ & Other outcomes \\
\hline Albanese [24] & 2019 & Italy & $\begin{array}{l}\text { Retrospective con- } \\
\text { trolled }\end{array}$ & $\begin{array}{l}n=178(\mathrm{M}=39 ; \\
\mathrm{F}=139 ; 72 \mathrm{VLCKD} \\
\text { and } 106 \mathrm{VLCD})\end{array}$ & $\begin{array}{l}\text { VLCKD: } \\
43.4 \pm 12.1 \\
\text { VLCD: } \\
43.5 \pm 11.8\end{array}$ & $\begin{array}{l}\text { BW: } 125.5 \pm 19.5 \mathrm{~kg} \\
\text { BMI: } 46.0 \pm 6.3 \\
\text { BW: } 120.9 \pm 22.6 \mathrm{~kg} \\
\text { BMI: } 43.6 \pm 6.9\end{array}$ & 3 weeks & - \\
\hline Bruci [25] & 2020 & Italy & $\begin{array}{l}\text { Prospective observa- } \\
\text { tional noncontrolled }\end{array}$ & $\begin{array}{l}n=93(\mathrm{M}=23 \\
\mathrm{F}=69)\end{array}$ & $51.3 \pm 12.2$ & $\begin{array}{l}\text { BW: } 92.40 \pm 18.31 \mathrm{~kg} \\
\text { BMI: } 33.85 \pm 5.84\end{array}$ & 2-3 months & $\begin{array}{l}\text { FM, FFM, glycemia, HbAlc, } \\
\text { cholesterol (total, LDL, and } \\
\text { HDL), and TG }\end{array}$ \\
\hline Colica [26] & 2017 & Italy & $\begin{array}{l}\text { RCT* including more } \\
\text { than a VLCKD arm } \\
\text { but not controlled vs. } \\
\text { other diets }\end{array}$ & $\begin{array}{l}n=40(20 \mathrm{VLCKD} \\
\text { and } 20 \mathrm{VLCKD}+ \\
\text { amino acids of } 50 \% \\
\text { proteins), and then } \\
\text { they were crossed over }\end{array}$ & $45.40 \pm 14.20$ & $\begin{array}{l}\text { BW: } 77.43 \pm 7.12 \mathrm{~kg} \\
\text { BMI: } 29.42 \pm 2.24 \\
\text { BW: } 82.23 \pm 14.60 \mathrm{~kg} \\
\text { BMI: } 29.85 \pm 3.98\end{array}$ & 3 weeks & Glycemia and HOMA-IR index \\
\hline de Luis [27] & 2016 & Spain & $\begin{array}{l}\text { RCT* including more } \\
\text { than VLCKD arm } \\
\text { but not controlled vs. } \\
\text { other diets }\end{array}$ & $\begin{array}{l}n=29(\mathrm{M}=12 ; \\
\mathrm{F}=17 ; 15 \mathrm{VLCKD} \\
\text { and } 14 \mathrm{VLCKD}+ \\
\text { DHA })\end{array}$ & $\begin{array}{l}44.3 \pm 11.7 \\
47.4 \pm 9.1\end{array}$ & $\begin{array}{l}\text { BW: } 92.2 \pm 13.1 \mathrm{~kg} \\
\text { BMI: } 32.95 \pm 1.9 \\
\text { BW: } 92.05 \pm 8.7 \mathrm{~kg} \\
\text { BMI: } 33.4 \pm 1.4\end{array}$ & 6 months & $\begin{array}{l}\text { WC, FM, glycemia, HOMA-IR } \\
\text { index, cholesterol (total, LDL, } \\
\text { and HDL), and TG }\end{array}$ \\
\hline Goday [28] & 2016 & Spain & RCT & $\begin{array}{l}n=89(\mathrm{M}=31 \\
\mathrm{F}=58 ; 45 \mathrm{VLCKD} \\
\text { and } 44 \mathrm{LCD})\end{array}$ & $\begin{array}{l}54.89 \pm 8.81 \\
54.17 \pm 7.97\end{array}$ & $\begin{array}{l}\text { BW: } 91.47 \pm 11.43 \mathrm{~kg} \\
\text { BMI: } 33.3 \pm 1.5 \\
\text { BW: } 90.0 \pm 11.3 \mathrm{~kg} \\
\text { BMI: } 32.9 \pm 1.6\end{array}$ & 4 months & $\begin{array}{l}\text { WC, glycemia, HbAlc, HOMA- } \\
\text { IR index, cholesterol (total, LDL, } \\
\text { and HDL), and TG }\end{array}$ \\
\hline $\begin{array}{l}\text { Gomez-Arbelaez } \\
\text { [29] }\end{array}$ & 2017 & Spain & $\begin{array}{l}\text { Prospective interven- } \\
\text { tional noncontrolled }\end{array}$ & $\begin{array}{l}n=20(\mathrm{M}=8 \\
\mathrm{F}=12)\end{array}$ & $47.2 \pm 10.2$ & $\begin{array}{l}\text { BW: } 95.9 \pm 16.3 \mathrm{~kg} \\
\text { BMI: } 35.5 \pm 4.4\end{array}$ & 4 months & WC, FM, and FFM \\
\hline $\begin{array}{l}\text { Gutiérrez-Repiso } \\
\text { [30] }\end{array}$ & 2019 & Spain & $\begin{array}{l}\text { RCT* including more } \\
\text { than a VLCKD arm } \\
\text { but not controlled vs. } \\
\text { other diets }\end{array}$ & $\begin{array}{l}n=33(\mathrm{M}=13 \\
\mathrm{F}=20)\end{array}$ & $\begin{array}{l}48.67 \pm 9.16 \\
47.00 \pm 8.97 \\
38.22 \pm 11.27\end{array}$ & $\begin{array}{l}\text { BW: } 92.74 \pm 15.86 \mathrm{~kg} \\
\text { BMI: } 32.82 \pm 1.76 \\
\text { BW: } 95.71 \pm 9.46 \mathrm{~kg} \\
\text { BMI: } 32.96 \pm 1.47 \\
\text { BW: } 90.58 \pm 10.83 \mathrm{~kg} \\
\text { BMI: } 33.14 \pm 1.47\end{array}$ & 4 months & $\begin{array}{l}\text { WC, FM, FFM, glycemia, } \\
\text { HOMA-IR index, cholesterol } \\
\text { (total, LDL, and HDL), and TG }\end{array}$ \\
\hline Leonetti [31] & 2015 & Italy & $\begin{array}{l}\text { Prospective } \\
\text { noncontrolled }\end{array}$ & $\begin{array}{l}n=50(\mathrm{M}=19 \\
\mathrm{F}=31)\end{array}$ & $47.4 \pm 11.2$ & $\begin{array}{l}\text { BW: } 150 \pm 26.3 \mathrm{~kg} \\
\text { BMI: } 53.5 \pm 8.4\end{array}$ & 1 month & $\begin{array}{l}\text { WC, cholesterol (total, LDL, and } \\
\text { HDL), and TG }\end{array}$ \\
\hline Merra [13] & 2016 & Italy & RCT & $\begin{array}{l}n=18(\mathrm{M}=5 ; \\
\mathrm{F}=13 ; 9 \mathrm{VLCKD} \\
\text { and } 9 \mathrm{VLCD})\end{array}$ & $\begin{array}{l}45.40 \pm 16.36 \\
49.33 \pm 13.78\end{array}$ & $\begin{array}{l}\text { BW: } 99.78 \pm 4.57 \mathrm{~kg} \\
\text { BMI: } 33.69 \pm 3.51 \\
\text { BW: } 74.77 \pm 5.04 \mathrm{~kg} \\
\text { BMI: } 29.21 \pm 1.07\end{array}$ & 3 weeks & WC, FM, and FFM \\
\hline Moreno [32] & 2014 & Spain & RCT & $\begin{array}{l}n=53(\mathrm{M}=6 \\
\mathrm{F}=48 ; 27 \mathrm{VLCKD} \\
\text { and } 26 \mathrm{LCD})\end{array}$ & $\begin{array}{l}44.4 \pm 8.6 \\
46.3 \pm 9.3\end{array}$ & $\begin{array}{l}\text { BW: } 97.9 \pm 18.9 \mathrm{~kg} \\
\text { BMI: } 35.1 \pm 4.5 \\
\text { BW: } 92.1 \pm 17.7 \mathrm{~kg} \\
\text { BMI: } 35.1 \pm 5.3\end{array}$ & 12 months & $\begin{array}{l}\text { WC, FM, FFM, glycemia, HbAlc, } \\
\text { cholesterol (total, LDL, and } \\
\text { HDL), and TG }\end{array}$ \\
\hline Moreno [10] & 2016 & Spain & RCT & $\begin{array}{l}n=45 \\
(22 \mathrm{VLCKD} \text { and } \\
23 \mathrm{LCD})\end{array}$ & $\begin{array}{l}44.6 \pm 7.8 \\
45.6 \pm 9.6\end{array}$ & $\begin{array}{l}\text { BW: } 99.1 \pm 19.7 \mathrm{~kg} \\
\text { BMI: } 35.2 \pm 4.8 \\
\text { BW: } 90.6 \pm 17.8 \mathrm{~kg} \\
\text { BMI: } 34.5 \pm 5.0\end{array}$ & 24 months & WC, FM, and VFM \\
\hline Perticone [33] & 2019 & Italy & RCT & $\begin{array}{l}n=56(\mathrm{M}=32 \\
\mathrm{F}=24 ; 28 \mathrm{VLCKD} \\
\text { and } 28 \mathrm{LCD})\end{array}$ & $\begin{array}{l}42.6 \pm 6.6 \\
50.9 \pm 13.3\end{array}$ & $\begin{array}{l}\text { BW: } 113.9 \pm 31.0 \mathrm{~kg} \\
\text { BMI: } 40.5 \pm 10.8 \\
\text { BW: } 107.5 \pm 18.5 \mathrm{~kg} \\
\text { BMI } 38.8 \pm 4.5\end{array}$ & 12 months & $\begin{array}{l}\text { WC, FM, FFM, glycemia, HbAlc, } \\
\text { HOMA-IR index, cholesterol } \\
\text { (total, LDL, and HDL), and TG }\end{array}$ \\
\hline Rubini [34] & 2015 & Italy & RCT & $\begin{array}{l}n=32(16 \mathrm{VLCKD} \\
\text { and } 16 \mathrm{MD})\end{array}$ & $\begin{array}{l}51.4 \pm 12.4 \\
44.7 \pm 13.9\end{array}$ & $\begin{array}{l}\text { BW: } 82.0 \pm 12.4 \mathrm{~kg} \\
\text { BMI: } 29.3 \pm 2.8 \\
\text { BW: } 77.2 \pm 9.8 \mathrm{~kg} \\
\text { BMI: } 27.5 \pm 2.8 .4\end{array}$ & 3.5 months & - \\
\hline Sajoux [35] & 2019 & Spain & Cohort controlled & $\begin{array}{l}n=79(\mathrm{M}=20 ; \\
\mathrm{F}=59 ; 20 \mathrm{VLCKD}, \\
20 \mathrm{LCD} \text { and } \\
39 \text { bariatric surgery })\end{array}$ & $\begin{array}{l}47.1 \pm 10.2 \\
49.9 \pm 9.3 \\
40.8 \pm 10.4\end{array}$ & $\begin{array}{l}\text { BW: } 96.0 \pm 16.3 \mathrm{~kg} \\
\text { BMI: } 35.5 \pm 4.4 \\
\text { BW: } 93.0 \pm 13.2 \mathrm{~kg} \\
\text { BMI: } 35.8 \pm 4.5 \\
\text { BW: } 121.3 \pm 21.5 \mathrm{~kg} \\
\text { BMI: } 45.6 \pm 6.2\end{array}$ & 4-6 months & FM, FFM, and HOMA-IR index \\
\hline Valenzano [36] & 2019 & Italy & $\begin{array}{l}\text { Prospective } \\
\text { noncontrolled }\end{array}$ & $\begin{array}{l}n=20(\mathrm{M}=10 \\
\mathrm{F}=10)\end{array}$ & $48 \pm 8.2$ & $\begin{array}{l}\text { BW: } 91.33 \pm 17.11 \mathrm{~kg} \\
\text { BMI: } 32.19 \pm 4.78\end{array}$ & 8 weeks & $\begin{array}{l}\text { FM, FFM, HbAlc, cholesterol } \\
\text { (total, LDL, and HDL), and TG }\end{array}$ \\
\hline
\end{tabular}

M, male; F, female; VFM, visceral fat mass; RCT, randomized controlled trial. 


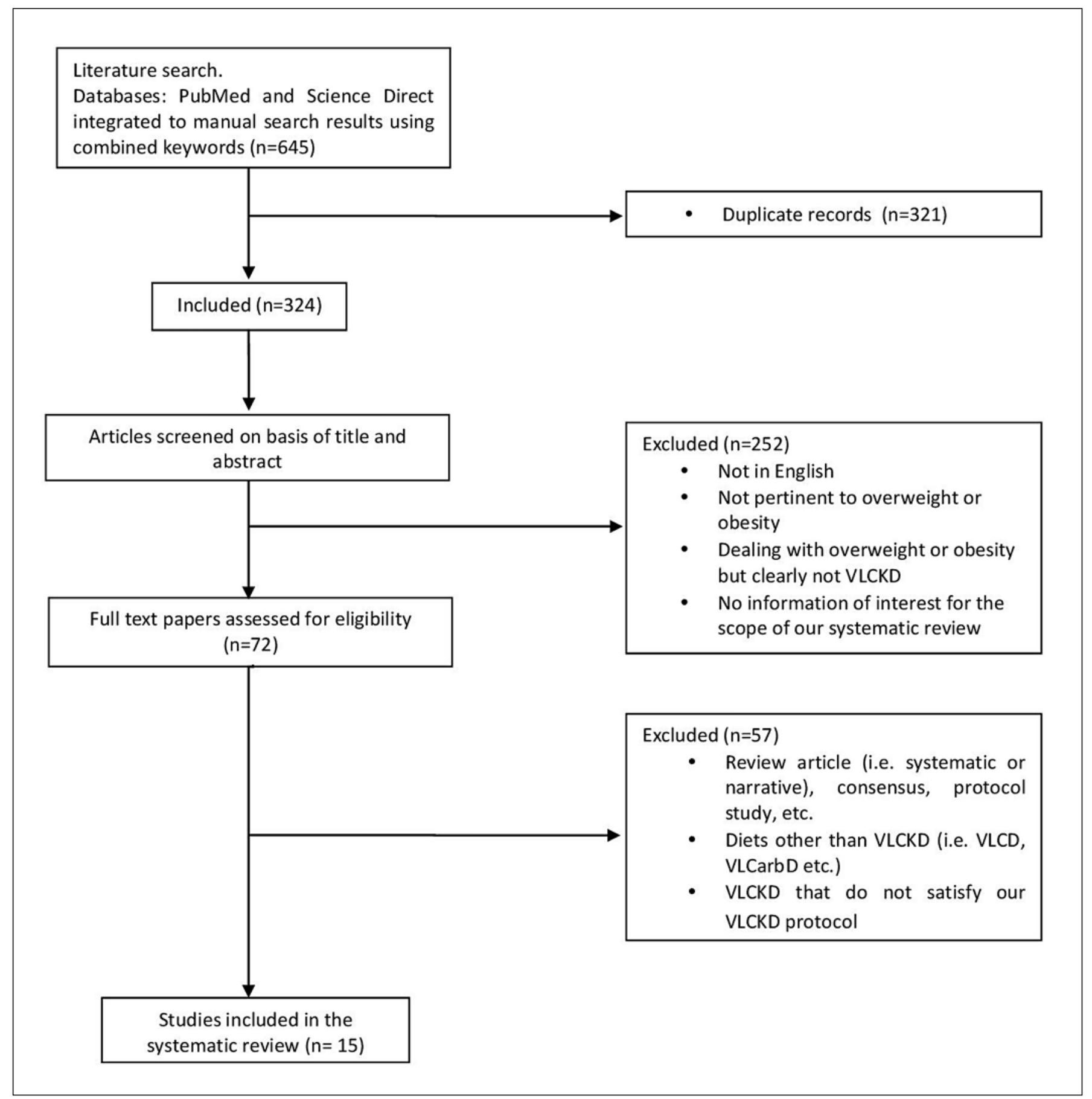

Fig. 2. Flow chart summarizing the study selection procedure.

\section{Narrative Synthesis}

Albanese et al. [24] included in a retrospective controlled study 178 patients (139 females and 39 males) with a mean age of 43 years and who were candidates for laparoscopic bariatric surgery. Seventy-two of those patients underwent a cycle of VLCKD in the 3 weeks before the bariatric procedure, and the other 106 followed VLCD for the same duration. The prediet mean BMI was $46.3 \pm 6.3$ for the VLCKD group and $43.1 \pm 6.9$ for VLCD, while immediately after diet and immediately prebariatric surgery 
the BMI values were $43.9 \pm 5.9$ and $41.9 \pm 6.8$. The absolute weight loss was significantly better in the VLCKD group than in the VLCD group $(5.8 \pm 2.4$ vs. $4.8 \pm 2.5 \mathrm{~kg}$; $p=0.008$ ).

Bruci et al. [25] conducted a prospective observational noncontrolled real-life study including 92 patients (mean age $=51.3 \pm 12.2$ years; BMI $33.85 \pm 5.84$ ) with obesity and mild kidney failure and who underwent nearly 3 months of VLCKD. Anthropometric, body composition, and biochemical data were obtained before and after the dietary intervention. A significant reduction in body weight ( $92.40 \pm 18.31$ vs. $76.82 \pm 14.95 \mathrm{~kg} ; p<0.0001)$, FM $(35.63 \pm 9.93$ vs. $24.40 \pm 9.00 \mathrm{~kg} ; p<0.0001)$, and FFM $(56.77 \pm 13.40$ vs. $52.42 \pm 10.89 \mathrm{~kg} ; p<0.0001)$ was observed, accompanied by improvements in glycemia $(95.32 \pm 13.26$ vs. $88.25 \pm 10.24 \mathrm{mg} / \mathrm{dL} ; p=0.002)$ and HbAlc (5.65 \pm 0.81 vs. $5.33 \pm 0.39 \%$; $p<0.0001$ ) and a reduction in total cholesterol $(206.91 \pm 45.65$ vs. $184.46 \pm 41.17 \mathrm{mg} / \mathrm{dL} ; p=0.004)$ and TG $(156.44 \pm 90.87$ vs. $102.62 \pm 35.71 \mathrm{mg} / \mathrm{dL} ; p=0.003$ ).

Colica et al. [26] carried out a randomized crossover trial including 42 patients (mean age: $45.40 \pm 14.20$ years) with a BMI $\geq 25$ and a FM $\geq 25 \%$ in males and $\geq 30$ in females. Patients were allocated to the following 2 arms over 3 weeks of follow-up: VLCKD-1 ( $n=20$; mean BMI $29.85 \pm 3.98$ ) in which $50 \%$ of the protein intake was replaced with synthetic amino acids and a regular VLCKD-2 ( $n=20$; mean BMI $29.42 \pm 2.24)$. At baseline, at the start and end of each arm, the health and nutritional status of all of the subjects were assessed by anthropometric analysis and a biochemical evaluation. A significant weight loss was observed in both arms of dietary treatment(VLCKD-1: $82.23 \pm 14.60$ vs. $77.62 \pm 12.37 \mathrm{~kg} ; p=0.00$; VLCKD-2: $77.43 \pm 7.12$ vs. $71.30 \pm 6.91 \mathrm{~kg} ; p=0.00)$, as was improvement in the HOMA-IR index (VLCKD-1: $3.80 \pm 2.85$ vs. $1.44 \pm 0.75 ; p=0.01$; VLCKD- $2: 3.35 \pm 1.45$ vs. $1.36 \pm 0.86$; $p=0.02)$. On the other hand, a significant decrease in glycemia was only found in VLCKD-2 (4.91 \pm 0.43 vs. $4.20 \pm 0.89 \mathrm{mmol} / \mathrm{L} ; p=0.03$ ), while no change in the lipid profile was noticed in both arms.

de Luis et al. [27] conducted a 6-months randomized controlled trial including 29 patients with obesity allocated to a VLCKD $(n=15$; mean age $=44.3 \pm 11.7$ years and BMI $32.95 \pm 1.9)$ or a VLCKD + DHA supplementation $(n=14$; mean age $=47.4 \pm 9.1$ years and BMI $33.4 \pm$ 1.4). The VLCKD group showed a significant reduction in body weight ( $92.2 \pm 13.1$ vs. $71.8 \pm 11.4 \mathrm{~kg}$; $p<0.05)$, FM $(30.3 \pm 6.1$ vs. $16.8 \pm 4.2 ; p<0.05)$, WC $(109.2 \pm$ 7.8 vs. $87.4 \pm 7.4 \mathrm{~cm} ; p<0.05)$, glycemia (101.6 \pm 11.3 vs. $88.9 \pm 7.6 \mathrm{mg} / \mathrm{dL} ; p<0.05)$, the HOMA-IR index $(3.1 \pm$
2.2 vs. $1.0 \pm 0.6 ; p<0.05)$, total cholesterol $(212.4 \pm 37.8$ vs. $183.4 \pm 31.2 \mathrm{mg} / \mathrm{dL})$, LDL cholesterol (139.4 \pm 33.0 vs. $119.2 \pm 28.9 \mathrm{mg} / \mathrm{dL} ; p<0.05)$, and TG $(135.0 \pm 50.6$ vs. $78.5 \pm 27.7 \mathrm{mg} / \mathrm{dL})$. Similarly, in the VLCKD + DHA group reductions in body weight $(92.1 \pm 8.7$ vs. $72.3 \pm 7.1$ kg; $p<0.05)$, FM (34.4 \pm 5.3 vs. $26.3 \pm 5.3 \mathrm{~kg} ; p<0.05)$, WC (109.1 \pm 8.0 vs. $89.1 \pm 5.2 \mathrm{~cm} ; p<0.05)$, glycemia $(105.0 \pm 17.5$ vs. $89.0 \pm 7.7 \mathrm{mg} / \mathrm{dL} ; p<0.05)$, the HOMAIR index $(3.8 \pm 1.9$ vs. $1.2 \pm 0.4 ; p<0.05)$, total cholesterol (195.8 \pm 41.9 vs. $177.1 \pm 43.2 \mathrm{mg} / \mathrm{dL} ; p<0.05)$, and TG $(150.6 \pm 71.2$ vs. $83.9 \pm 31.4 \mathrm{mg} / \mathrm{dL})$ were observed.

Goday et al. [28] conducted a controlled trial including 89 adult patients with obesity and type 2 diabetes randomly allocated to either VLCKD $(n=45$; mean age $=$ $54.89 \pm 8.81$ years and BMI 33.25 \pm 1.52 ) or standard LCD based on American Diabetes Association (ADA) guidelines $(n=45$; mean age $=54.17 \pm 7.97$ years and $\mathrm{BMI}$ $32.88 \pm 1.60)$. Clinical outcomes were assessed at baseline and at the 4-month follow-up. A significant reduction in body weight $(91.5 \pm 11.4$ vs. $76.8 \pm 9.1 \mathrm{~kg} ; p<$ $0.0001)$, WC (108.1 \pm 8.6 vs. $96.1 \pm 7.6 \mathrm{~cm} ; p<0.0001)$, fasting glycemia $(136.9 \pm 34.4$ vs. $108.9 \pm 20.4 \mathrm{mg} / \mathrm{dL}$; $p<0.0001)$, HbA1c $(6.9 \pm 1.1$ vs. $6.0 \pm 0.7 \%$ total $\mathrm{Hb} ; p<$ $0.0001)$, the HOMA-IR index (6.9 \pm 4.4 vs. $3.5 \pm 1.9 ; p<$ $0.0001)$, and TG $(150.5 \pm 54.4$ vs. $114.6 \pm 57.2 \mathrm{mg} / \mathrm{dL}$; $p=0.004)$ was observed with a VLCKD. On the other hand, a reduction only in WC $(105.8 \pm 8.5$ vs. $100.4 \pm$ $9.2 \mathrm{~cm} ; p=0.048)$ and the HOMA-IR index (5.8 $\pm 2.9 \mathrm{vs}$. $4.6 \pm 2.5 ; p=0.001$ ) was observed in the LCD group.

Gomez-Arbelaez et al. [29] conducted a prospective interventional noncontrolled study in 20 adult patients with obesity (mean age 47.2 \pm 10.2 years and BMI $35.5 \pm$ 4.4) and who underwent a nutritional intervention based on a VLCKD. Anthropometric and body composition assessments were conducted at baseline and at a mean of 40 , 90, and 120 days. At the 6-month follow-up, significant weight loss $(95.9 \pm 16.3$ vs. $75.1 \pm 11.8 \mathrm{~kg} ; p<0.05)$ and a reduction in WC $(109.4 \pm 12.8$ vs. $88.6 \pm 10.1 \mathrm{~cm} ; p<$ $0.05), \mathrm{FM}(42.2 \pm 9.1$ vs. $25.7 \pm 5.8 \mathrm{~kg} ; p<0.05)$, and FFM $(52.8 \pm 10.2$ vs. $49.0 \pm 9.7 \mathrm{~kg} ; p<0.05)$ were observed.

Gutiérrez-Repiso et al. [30] conducted a randomized controlled study recruiting 33 patients with obesity (BMI $\geq 30$ ) treated with a weight loss program VLCKD followed by an LCD over a period of 4 months of follow-up. Participants were allocated randomly to the following 3 arms: those supplemented with synbiotics during the VLCKD and the LCD $(n=15$; mean age $48.67 \pm 9.16$ years and BMI $32.82 \pm 1.76)$, those supplemented with a placebo during the VLCKD and synbiotics during the LCD phase $(n=9$; mean age $=47.00 \pm 8.97$ years and BMI 
$32.96 \pm 1.47)$, and a control group receiving a placebo during the VLCKD and the LCD ( $n=9$; mean age = $38.22 \pm 11.27$ years and BMI $33.14 \pm 1.47)$. In all 3 treatment arms, calorie restriction induced significant changes in body weight (arm 1: $92.74 \pm 15.86$ vs. $79.78 \pm 13.92$ $\mathrm{kg}, p<0.01$; $\operatorname{arm} 2: 95.71 \pm 9.46$ vs. $76.63 \pm 12.83 \mathrm{~kg}, p<$ 0.01 ; and arm 3: $90.58 \pm 10.83$ vs. $77.62 \pm 8.22 \mathrm{~kg}, p<$ $0.01)$, WC (arm 1: $110.40 \pm 10.88$ vs. $97.53 \pm 9.13 \mathrm{~cm}$, $p<0.01$; arm 2: $111.22 \pm 7.12$ vs. $95.67 \pm 7.09 \mathrm{~cm}, p<0.01$, and arm 3: $109.67 \pm 6.30$ vs. $93.67 \pm 5.74 \mathrm{~cm}, p<0.01$ ), FM (arm 1: $38.99 \pm 8.35$ vs. $26.97 \pm 3.36 \mathrm{~kg}, p<0.01$; arm 2: $36.04 \pm 5.89$ vs. $23.63 \pm 5.39 \mathrm{~kg}, p<0.01$; and arm 3 : $34.20 \pm 4.35$ vs. $24.33 \pm 5.33 \mathrm{~kg}, p<0.01$ ), and FFM (arm 2: $59.67 \pm 11.31$ vs. $55.98 \pm 9.80 \mathrm{~kg}, p<0.01$; and arm 3 : $56.40 \pm 11.69$ vs. $53.29 \pm 10.45 \mathrm{~kg}, p<0.01)$. Significant improvements were also observed in biochemical variables such as glycemia (arm 1: $93.13 \pm 10.80$ vs. $87.93 \pm$ $10.24 \mathrm{mg} / \mathrm{dL}, p<0.05$; and arm 3: $88.77 \pm 11.37$ vs. $78.44 \pm 4.30 \mathrm{mg} / \mathrm{dL}, p<0.01$ ), HDL cholesterol (arm 1: $57.07 \pm 10.56$ vs. $63.57 \pm 11.02 \mathrm{mg} / \mathrm{dL}, p<0.05$; arm 2 : $56.62 \pm 11.68$ vs. $67.11 \pm 15.96 \mathrm{mg} / \mathrm{dL}, p<0.05$; and arm 3: $50.77 \pm 14.43$ vs. $62.00 \pm 15.81 \mathrm{mg} / \mathrm{dL}, p<0.01)$, and TG (arm 1: $133.33 \pm 84.02$ vs. $89.53 \pm 31.37 \mathrm{mg} / \mathrm{dL}, p<$ 0.05 ; and arm 2: $146.11 \pm 77.85$ vs. $75.55 \pm 28.71 \mathrm{mg} / \mathrm{dL}$, $p<0.05)$.

Leonetti et al. [31] conducted a prospective noncontrolled study in which they evaluated the effectiveness of a sequential diet composed of a VLCKD (10 days), followed by a VLCD (10 days) and finally a LCD (10 days), in 50 patients affected by obesity (mean age $=47.4 \pm 11.2$ years and BMI $53.5 \pm 8.4$ ) who were scheduled for laparoscopic bariatric surgery. Body weight (150.4 \pm 26.3 vs. $137.6 \pm 22.5 \mathrm{~kg} ; p<0.0001)$, BMI (53.5 \pm 8.4 vs. $49.2 \pm 8.7$; $p<0.0001)$, and WC $(145.0 \pm 15.6$ vs. $126.4 \pm 16.5 \mathrm{~cm}$; $p<0.003)$ were significantly lower after 1 month of a sequential diet regime. However, the lipid profile did not show significant changes from baseline to 1 month.

Merra et al. [13] conducted a double-blind study in 18 adult participants with a BMI $\geq 25$ and a $\mathrm{FM} \geq 25 \%$ in males and $\geq 30$ in females and who were randomized to a VLCKD integrated with amino acids $(n=9$; mean age $=$ $45.50 \pm 16.39$ years and BMI $33.69 \pm 3.51)$ or a VLCD $(n=9$; mean age $=49.33 \pm 13.78$ years and BMI $29.21 \pm$ 1.07). Anthropometric data and body composition were assessed at baseline and after 3 weeks. Significant weight loss was noticed in the VLCKD $(99.78 \pm 4.57$ vs. $92.80 \pm$ $4.78 \mathrm{~kg} ; p=0.00)$ and VLCD (74.77 \pm 5.04 vs. $68.80 \pm 4.24$ $\mathrm{kg} ; p=0.00)$ groups, accompanied by a reduction in FM (VLCKD: $37.24 \pm 9.31$ vs. $34.79 \pm 9.38 \mathrm{~kg} ; p=0.02$; VLCD: $33.06 \pm 3.60$ vs. $30.59 \pm 3.65 \mathrm{~kg} ; p=0.00$ ). Interestingly, the VLCKD group showed a reduction in WC $(103.90 \pm$ 5.98 vs. $98.40 \pm 5.91 \mathrm{~cm} ; p=0.00)$ and conservation of the FFM (53.01 \pm 12.86 vs. $54.93 \pm 8.96$; $p=0.75)$, while the VLCD group showed no change in WC $(84.72 \pm 2.73$ vs. $83.75 \pm 7.05 \mathrm{~cm} ; p=0.34)$ and a significant decrease in FFM (39.00 \pm 3.03 vs. $35.70 \pm 3.09 \mathrm{~kg} ; p=0.00)$.

Moreno et al. [32] conducted a controlled trial including a total of 79 patients with obesity randomized to a VLCKD $(n=27$; mean age $44.4 \pm 8.6$ years, body weight $97.9 \pm 18.9 \mathrm{~kg}$, and BMI $35.1 \pm 4.5)$ or a standard LCD ( $n=26$; mean age $46.3 \pm 9.3$ years, body weight: $92.1 \pm$ $17.7 \mathrm{~kg}$, and BMI $35.1 \pm 5.3$ ) over a 1-year follow-up. Both arms received external support counselling to perform physical activity and adhered to the diet. Body weight, WC, and BMI were the primary outcome measures. The main secondary outcomes were cardiovascular risk factors, adherence, body composition (i.e., FM and FFM), and other metabolic parameters (i.e., FBG, HbA1c, HDL and LDL cholesterol, TG, and others). Briefly, the weight reduction in the VLCKD and LCD groups was $13.6 \pm 3.9$ and $4.8 \pm 2.7 \mathrm{~kg}(p<0.0001)$, respectively, at 2 months, and this significant difference was maintained at the end of the follow-up $(19.9 \pm 12.3$ vs. $7.0 \pm 5.6 \mathrm{~kg}$ : $p<0.0001)$. Moreover, at the 1-year follow-up most of the patients in the VLCKD group had lost $>10 \%$ of their initial body weight and their lean mass was well preserved. The same authors later published their data on a longer follow-up that reached 24 months [10], apparently in a subgroup of their previous study, with potential samples overlapping; their aim was to evaluate the long-term effect of VLCKD $(n=22)$ versus LCD $(n=23)$ in terms of body weight, $\mathrm{W}$ and FM in a randomized trial. At 24 months, the VLCKD, when compared to the LCD, induced a significantly major reduction in body weight $(-12.5 \mathrm{vs} .-4.4 \mathrm{~kg} ; p<0.001)$, WC (-11.6 vs. $4.1 \mathrm{~cm} ; p<0.001), \mathrm{FM}(-8.8$ vs. $3.8 \mathrm{~kg} ; p<$ $0.001)$, and visceral fat $(-600 \mathrm{~g}$ vs. $-202 \mathrm{~g} ; p<0.001)$.

Perticone et al. [33] conducted a randomized controlled trial enrolling 56 outpatients with obesity who went on either a traditional standard hypocaloric Mediterranean diet $(n=28$; mean age $=50.9 \pm 13.3$ years, and BMI $38.8 \pm 4.5)$ or a VLCKD $(n=28$; mean age $=42.6 \pm$ 6.6 years, and BMI $40.5 \pm 10.8$ ). After a 1-year follow-up, the standard hypocaloric Mediterranean diet group showed significant improvement in the glycemic profile represented by FBG $(115.3 \pm 32.6$ vs. $99.7 \pm 11.4 \mathrm{mg} / \mathrm{dL}$; $p=0.048), \mathrm{HbA} 1 \mathrm{c}(6.5 \pm 1.5$ vs. $5.4 \pm 0.18 \% \mathrm{Hb}$ total; $p=$ $0.034)$, and the HOMA-IR index (7.4 \pm 0.9 vs. $3.5 \pm 0.4$; $p=0.001)$, as well as a reduction in TG $(158.5 \pm 62.3 \mathrm{vs}$. $113.0 \pm 21.5 \mathrm{mg} / \mathrm{dL} ; p=0.039)$. On the other hand, reductions in WC $(119.1 \pm 22.9$ vs. $95.0 \pm 17.4 \mathrm{~cm} ; p=0.044)$, 
HbA1c ( $6.1 \pm 1.4$ vs. $5.2 \pm 0.15 \%$ Hb total; $p=0.022)$, the HOMA-IR index (7.3 \pm 0.7 vs. $2.6 \pm 0.2 ; p<0.0001)$, and TG $(151.3 \pm 50.0$ vs. $72.3 \pm 29.6 \mathrm{mg} / \mathrm{dL} ; p=0.004)$ were observed in the VLCKD group.

Rubini et al. [34] conducted a 2 -arm randomized controlled trial including 32 healthy subjects with overweight (BMI from 25 to 30 ). The first arm ( $n=16$; mean age $51.4 \pm 12.4$ years, body weight $82.0 \pm 12.4 \mathrm{~kg}$, and BMI $29.3 \pm 2.8$ ) followed a VLCKD for 20 days, switching to a low-carbohydrate nonketogenic diet for 20 days more, and finally to a Mediterranean diet for 2 more months. The mean body weight at 20 days, 40 days, and 2 months was $77.8 \pm 12.0,74.8 \pm 11.7$, and $73.5 \pm 12.6 \mathrm{~kg}$, respectively. The second arm $(n=16$; mean age $44.7 \pm$ 13.9 years, body weight $77.2 \pm 9.8 \mathrm{~kg}$, and BMI $27.5 \pm$ 2.8.4) followed a Mediterranean diet over the same duration, with a mean body weight at 20 days, 40 days, and 2 months of $74.4 \pm 10.0,72.5 \pm 9.6$, and $72.1 \pm 10.7 \mathrm{~kg}$, respectively. Briefly, the average weight loss was $8.4 \mathrm{~kg}$ for the VLCKD group and $5.1 \mathrm{~kg}$ for the Mediterranean diet group at 3.5 months of follow-up. Both groups showed a reduction in FM, which was more significant for the VLCKD group.

Sajoux et al. [35] published a controlled study that included 79 patients with obesity; one group went on a VLCKD $(n=20$; mean age $47.1 \pm 10.2$ years and BMI 35.5 \pm 4.4 ), another group underwent a nutritional intervention based on a LCD $(n=20$; mean age $49.9 \pm 9.3$ years and BMI $35.8 \pm 4.5$ ), and a third group comprised of those with morbid obesity underwent bariatric surgery (i.e., Roux-en-Y gastric bypass, biliopancreatic diversion, and sleeve gastrectomy; $n=39$; mean age $40.8 \pm 10$. 4 years, and BMI $45.6 \pm 6.2$ ). All of the patients included in this study achieved a statistically significant weight loss. At 4-6 months of follow-up, the VLCKD diet induced a 20-kg

Fig. 3. Forest plots of the changes in clinical outcomes. a Weight loss (kg) after 1 month of VLCKD. b Weight loss as BMI after 1 month of VLCKD. c Weight loss (kg) after 2 months of VLCKD. d Weight loss as BMI after 2 months of VLCKD. e Weight loss (kg) after 4-6 months of VLCKD. $\mathbf{f}$ Weight loss as BMI after 4-6 months of VLCKD. $\mathbf{g}$ Weight loss (kg) after 12 months of VLCKD. h Weight loss as BMI after 12 months of VLCKD. i Comparison of mean weight loss $(\mathrm{kg})$ between VLCKD and controls. j Comparison of mean weight loss as BMI between VLCKD and controls. k Reduction of WC $(\mathrm{cm})$ after VLCKD. I Comparison of mean difference in WC $(\mathrm{cm})$ between VLCKD and controls. $\mathbf{m}$ Reduction of FM (kg) after VLCKD. $\mathbf{n}$ Comparison of the mean difference in FM (kg) between VLCKD and controls. o Reduction of FFM $(\mathrm{kg})$ after VLCKD. $\mathbf{p}$ Comparison of the mean difference in FFM $(\mathrm{kg})$ between VLCKD and controls. q Reduction of glycemia (mg/dL) reduction of body weight $(96.0 \pm 16.3$ vs. $76.6 \pm 11.1 \mathrm{~kg}$; $p<0.05)$ compared to the $\sim 38 \mathrm{-kg}$ reduction induced by bariatric surgery $(121.3 \pm 21.5$ vs. $81.7 \pm 14.3 \mathrm{~kg} ; p<0.05)$ and the $\sim 9 \mathrm{~kg}$ reduction after the $\operatorname{LCD}(93.0 \pm 13.2$ vs. 87.6 $\pm 12.3 \mathrm{~kg} ; p<0.05)$. This was accompanied by a loss of $\sim 16$ $\mathrm{kg}$ of FM $(42.2 \pm 9.2$ vs. $25.7 \pm 5.8 \mathrm{~kg} ; p<0.05)$ and $\sim 4 \mathrm{~kg}$ of FFM (52.8 \pm 10.3 vs. $49.1 \pm 9.7 \mathrm{~kg} ; p<0.05)$ in the VLCKD group. Patients who underwent bariatric surgery showed a $\sim 31-\mathrm{kg}$ reduction of FM $(62.57 \pm 14.9$ vs. $31.7 \pm$ $8.2 \mathrm{~kg} ; p<0.05)$ and a $\sim 7-\mathrm{kg}$ reduction of FFM (56.7 \pm 9.9 vs. $49.6 \pm 8.5 \mathrm{~kg} ; p<0.05)$, and the LCD induced a $\sim 7-\mathrm{kg}$ reduction of FM $(34.6 \pm 8.3$ vs. $30.7 \pm 7.6 \mathrm{~kg} ; p<0.05)$ and a $\sim 2-\mathrm{kg}$ reduction of FFM $(57.6 \pm 11.6$ vs. $56.9 \pm 11.2 \mathrm{~kg}$; $p<0.05)$. Finally, the 3 weight loss approaches induced a significant improvement in the HOMA-IR index, with the larger improvement induced by the VLCKD.

Finally, Valenzano et al. [36] conducted small prospective noncontrolled study including 20 patients with obesity (mean age $48 \pm 8.2$ years and BMI $32.19 \pm 4.78$ ) who underwent an 8-week nutritional intervention based on a VLCKD. The VLCKD resulted in significant weight loss (91.33 \pm 17.11 vs. $78.73 \pm 13.36 \mathrm{~kg} ; p<0.001)$ and a reduction of total $(220.13 \pm 50.77$ vs. $173.91 \pm 32.93 \mathrm{mg} / \mathrm{dL} ; p<0.05)$ and LDL cholesterol $(141.83 \pm 36.48$ vs. $107.57 \pm 27.72 \mathrm{mg} / \mathrm{dL}$; $p<0.05)$, as well as TG $(135.54 \pm 125.27$ vs. $83.25 \pm 26.14$ $\mathrm{mg} / \mathrm{dL} ; p<0.05)$. Finally, a significant decrease in total FM $(39,208.77 \pm 1,432.55$ vs. $27,377.0 \pm 1,217.48 \mathrm{~g} ; p<0.001)$ and visceral adipose tissue $(1,541.55 \pm 141.63$ vs. $927.79 \pm$ $104.92 \mathrm{~g} ; p<0.001$ ) was observed.

\section{Meta-Analysis}

Fourteen of the 15 included studies underwent metaanalysis, and only 1 study was excluded [10] because of potential sample overlapping. The primary outcome was the change in body weight and BMI from baseline to fol-

after VLCKD. $\mathbf{r}$ Comparison of the mean change in glycemia $(\mathrm{mg} /$ $\mathrm{dL}$ ) between VLCKD and controls. s Change in HbA1c after VLCKD. $\mathbf{t}$ Comparison of the mean change in HbAlc between VLCKD and controls. u Change in HOMA-IR after VLCKD. $\mathbf{v}$ Comparison of the mean change in HOMA-IR between VLCKD and controls. w Change in serum total cholesterol $(\mathrm{mg} / \mathrm{dL})$ after VLCKD. $\mathbf{x}$ Comparison of the mean change in serum total cholesterol (mg/dL) between VLCKD and controls. $y$ Change in serum LDL cholesterol (mg/dL) after VLCKD. z Comparison of the mean change in serum LDL cholesterol ( $\mathrm{mg} / \mathrm{dL}$ ) between VLCKD and controls. aa Change in serum HDL cholesterol $(\mathrm{mg} / \mathrm{dL})$ after VLCKD. bb Comparison of the mean change in serum HDL cholesterol $(\mathrm{mg} / \mathrm{dL})$ between VLCKD and controls. cc Change in serum TG $(\mathrm{mg} / \mathrm{dL})$ after VLCKD. dd Comparison of the mean change in serum TG $(\mathrm{mg} / \mathrm{dL})$ between VLCKD and controls.

(For figure see next pages.) 


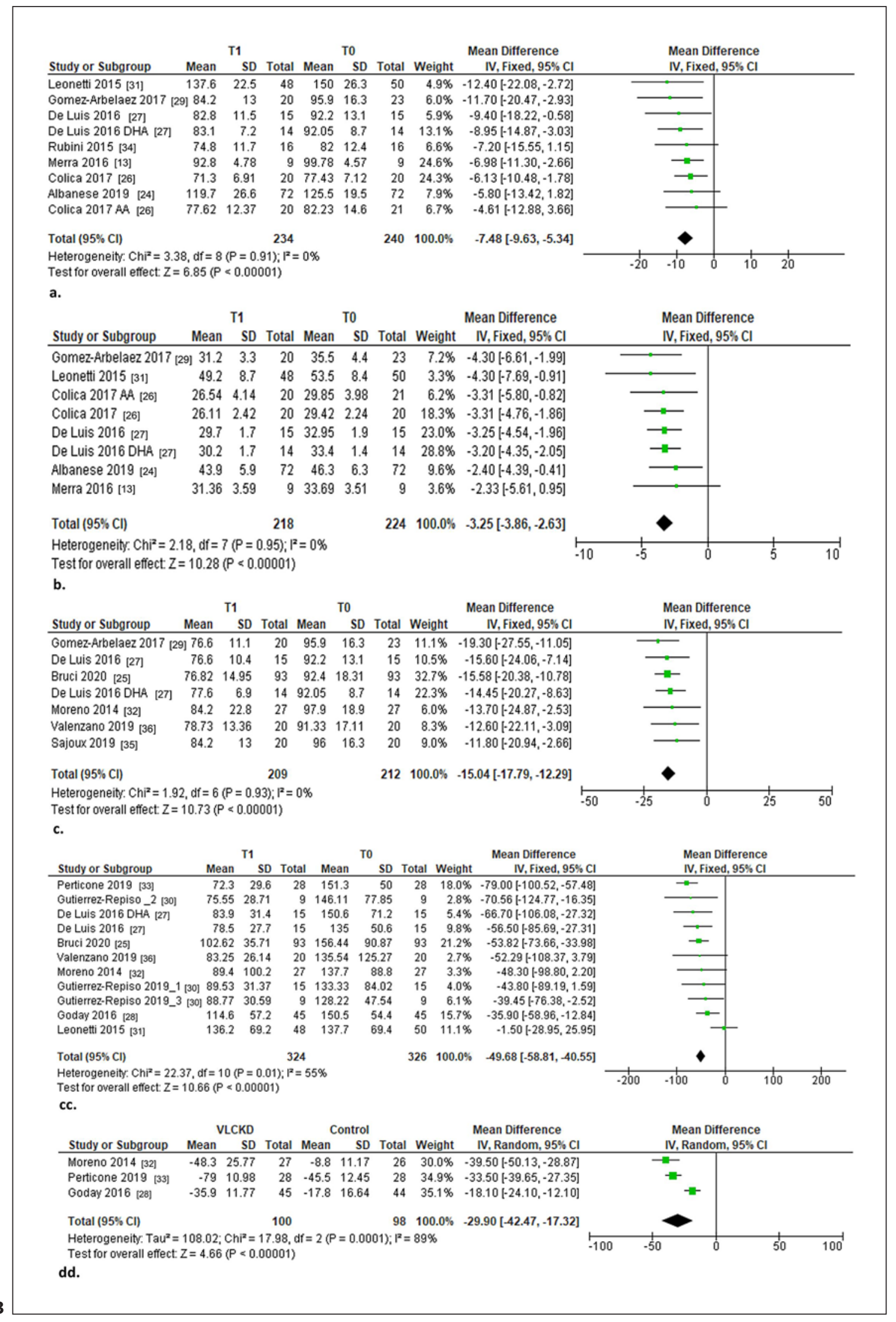

(Figure continued on next pages.) 


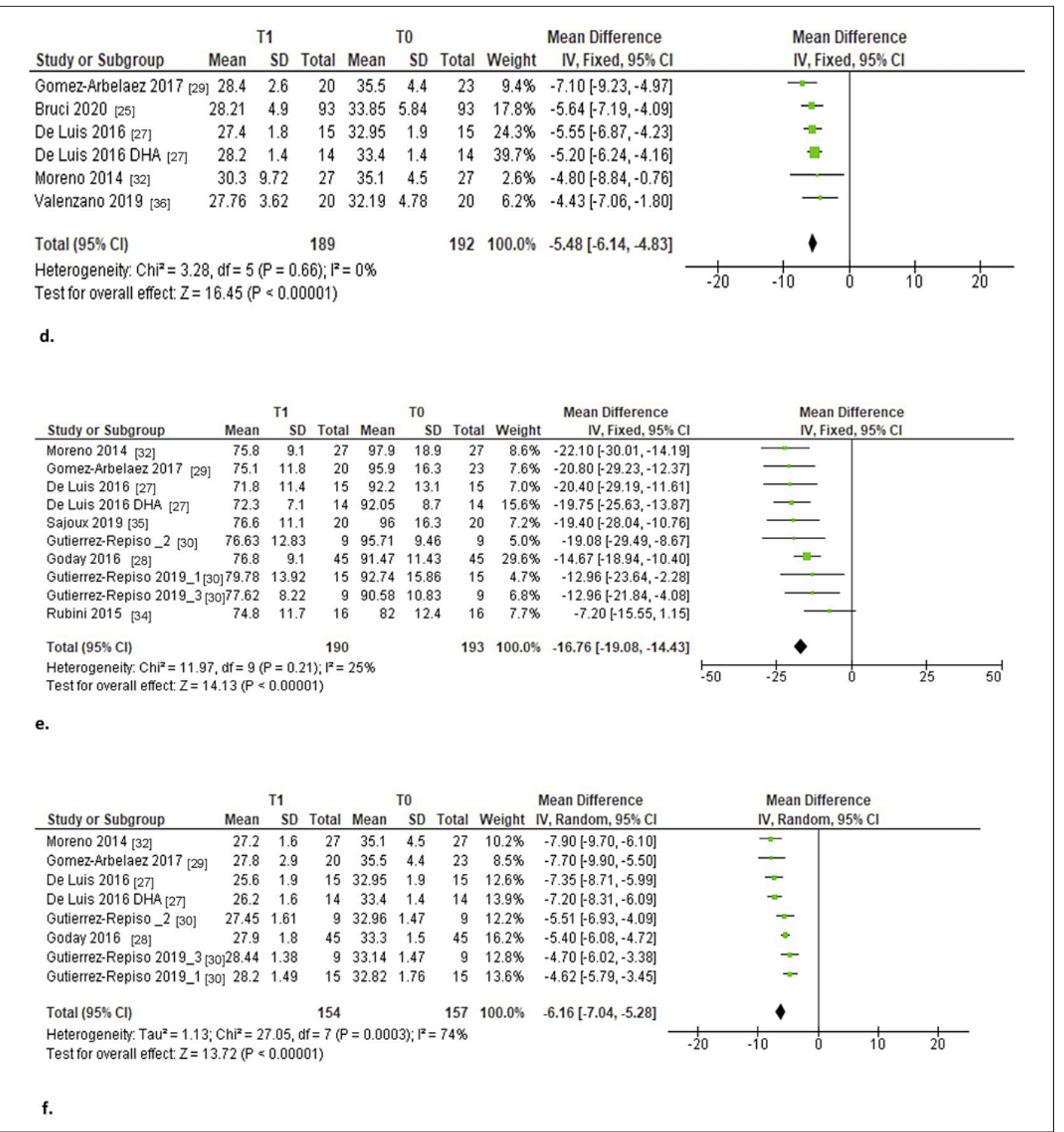

(Figure continued on next pages.)

low-up with a VLCKD. Secondary outcomes were changes in body composition (expressed as WC in cm, FM in $\mathrm{kg}$, and FFM in $\mathrm{kg}$ ), the glycemic profile (expressed as glycemia in $\mathrm{mg} / \mathrm{dL}$, glycosylated hemoglobin HbAlc in \% total $\mathrm{Hb}$, and the HOMA-IR index), and the lipid profile (expressed as total cholesterol, in LDL and HDL cholesterol, and TG in $\mathrm{mg} / \mathrm{dL}$ ) from baseline to follow-up with a VLCKD. Moreover, comparisons between a VLCKD and any other weight loss intervention (i.e., mainly LCD) of the same duration were performed (Fig. 3). 


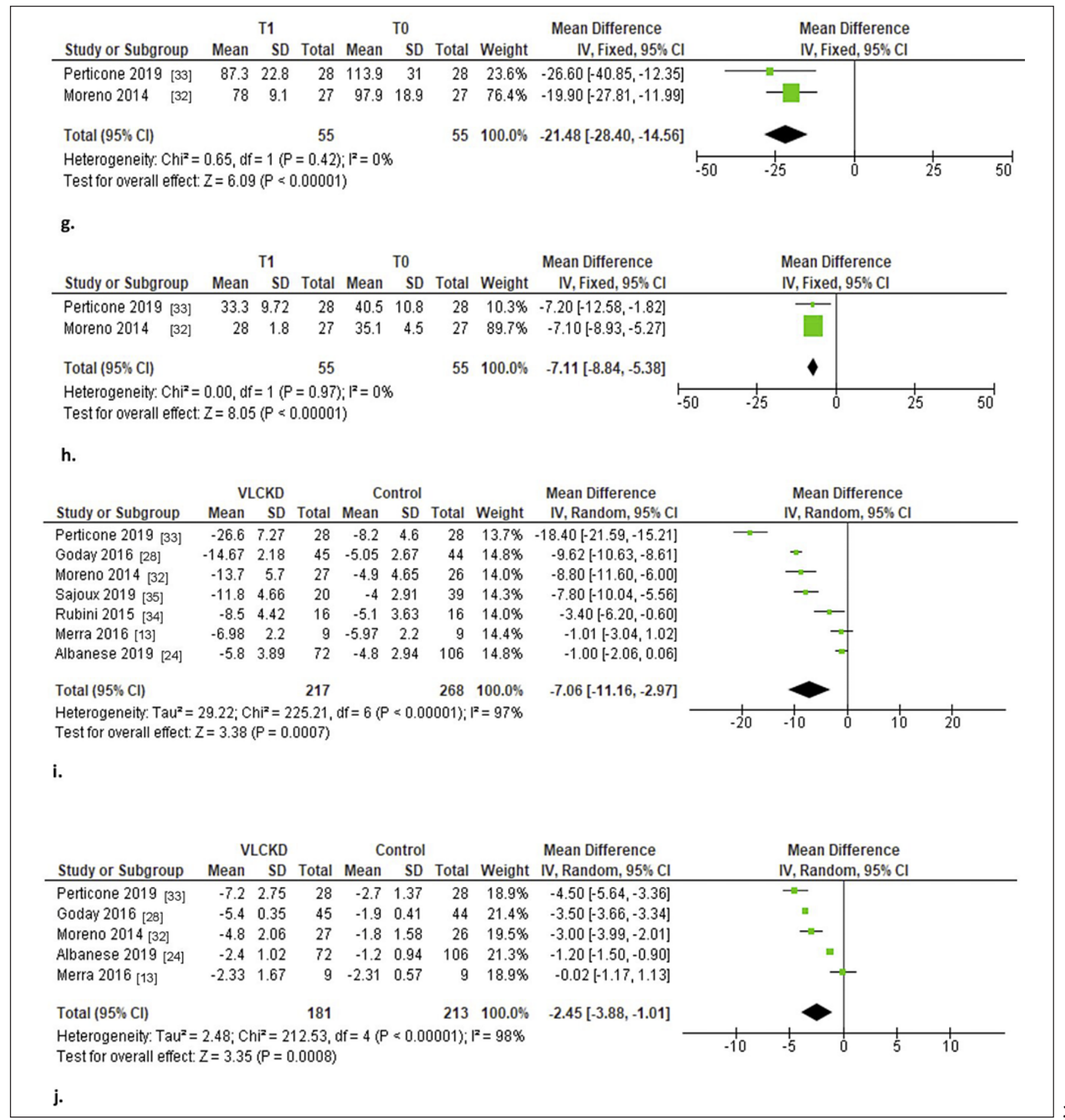

(Figure continued on next pages.)

Body Weight Status

At the 1-month follow-up a VLCKD was associated with a weight loss of $-7.48 \mathrm{~kg}$ (95\% CI -9.63 to $-5.34 ; I^{2}=$ $0 \%)$ and a reduction of the BMI of -3.25 (95\% CI -3.86 to $-2.63 ; I^{2}=0 \%$; Fig. $\left.3 \mathrm{a}, \mathrm{b}\right)$. In the same direction, at the 2-month follow-up a VLCKD was associated with a weight loss of $-15.04 \mathrm{~kg}\left(95 \% \mathrm{CI}-17.79\right.$ to $\left.-12.29 ; I^{2}=0 \%\right)$ and a reduction of the BMI of -5.48 (95\% CI -6.14 to -4.83 ; $I^{2}=0 \%$; Fig. 3c, d). At the intermediate weight loss followup, i.e., at the 4- to 6-month follow-up, a VLCKD was as- 


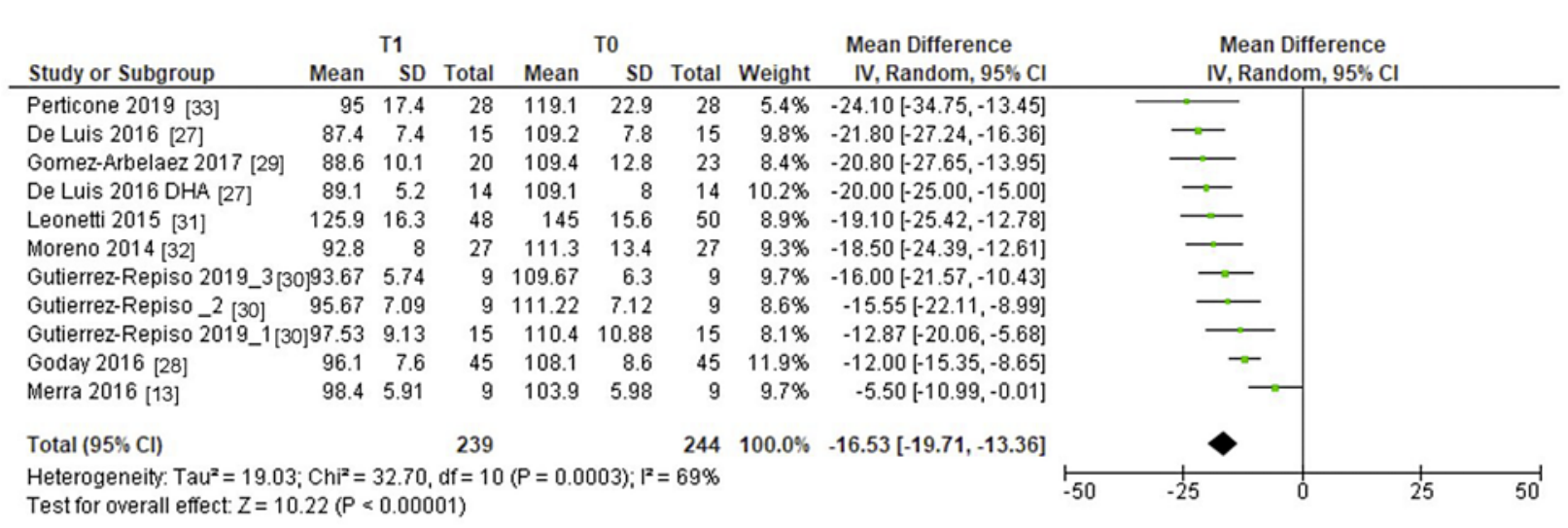

\section{k.}

\begin{tabular}{|c|c|c|c|c|c|c|c|c|c|c|c|c|}
\hline \multirow[b]{2}{*}{ Study or Subgroup } & \multicolumn{3}{|c|}{ VLCKD } & \multicolumn{3}{|c|}{ Control } & \multirow[b]{2}{*}{ Weight } & \multirow{2}{*}{$\begin{array}{l}\text { Mean Difference } \\
\text { IV, Random, } 95 \% \mathrm{Cl}\end{array}$} & \multirow{2}{*}{\multicolumn{4}{|c|}{$\begin{array}{c}\text { Mean Difference } \\
\text { IV, Random, } 95 \% \mathrm{Cl}\end{array}$}} \\
\hline & Mean & SD & Total & Mean & SD & Total & & & & & & \\
\hline Moreno 2014 [32] & -18.5 & 3 & 27 & -7 & 3.44 & 26 & $25.5 \%$ & $-11.50[-13.24,-9.76]$ & & $-m-$ & & \\
\hline Perticone 2019 [32] & -24.1 & 5.44 & 28 & -13.4 & 3.58 & 28 & $23.6 \%$ & $-10.70[-13.11,-8.29]$ & & $-m-$ & & \\
\hline Goday 2016 [28] & -12 & 1.71 & 45 & -5.4 & 1.89 & 44 & $27.4 \%$ & $-6.60[-7.35,-5.85]$ & & $=$ & & \\
\hline Merra 2016 [13] & -5.5 & 2.8 & 9 & -0.97 & 2.52 & 9 & $23.5 \%$ & $-4.53[-6.99,-2.07]$ & & -- & & \\
\hline Total $(95 \% \mathrm{CI})$ & & & 109 & & & 107 & $100.0 \%$ & $-8.33[-11.34,-5.33]$ & & & & \\
\hline $\begin{array}{l}\text { Heterogeneity. Tau } \\
\text { Test for overall effect }\end{array}$ & $\begin{array}{l}8.43 ; C \\
Z=5.44\end{array}$ & $\begin{array}{l}2=38 \\
P<0\end{array}$ & $\begin{array}{l}8.11, d f \\
.00001\end{array}$ & $f=3(P<$ & $<0.00$ & 001); $\left.\right|^{2}=$ & $=92 \%$ & & -20 & -10 & $\frac{1}{10}$ & 20 \\
\hline
\end{tabular}

I.

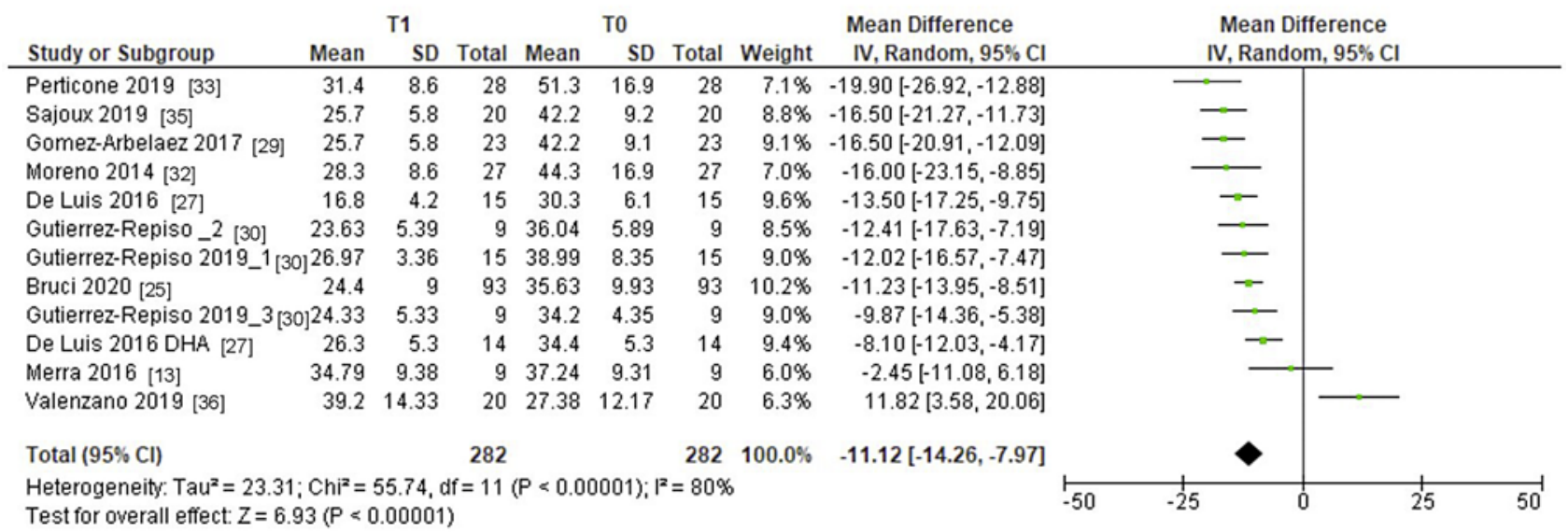

m.

(Figure continued on next pages.)

sociated with a weight loss of $-16.76 \mathrm{~kg}$ (95\% CI -19.08 to $\left.-14.43 ; I^{2}=25 \%\right)$ and a reduction of the BMI of $-6.16(95 \%$ CI -7.04 to $-5.28 ; I^{2}=74 \%$; Fig. $\left.3 e, f\right)$. At the 12 -month follow-up, a VLCKD was associated with a weight loss of $-21.48 \mathrm{~kg}\left(95 \% \mathrm{CI}-28.40\right.$ to $\left.-14.56 ; I^{2}=0 \%\right)$ and a reduction of the BMI of -7.11 ( $95 \%$ CI -8.84 to $-5.38 ; I^{2}=0 \%$;
Fig. 2g, h). In a comparison between a VLCKD and other weight loss interventions of the same duration, the former showed a major significant mean weight loss $(p=0.0007)$ in terms of body weight $(-7.06 \mathrm{~kg}$; $95 \% \mathrm{CI}-11.16$ to -2.97 ; $\left.I^{2}=97 \% ; p=0.0007\right)$ and BMI $(-2.45 ; 95 \% \mathrm{CI}-3.88$ to $-1.01 ; I^{2}=98 \% ; p=0.0008$; Fig. $\left.3 \mathrm{i}, \mathrm{j}\right)$. 


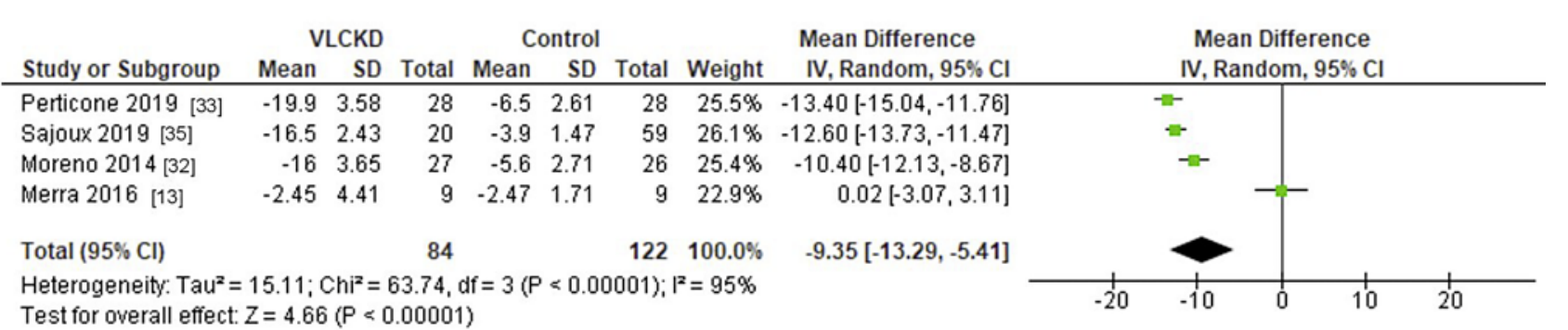

n.

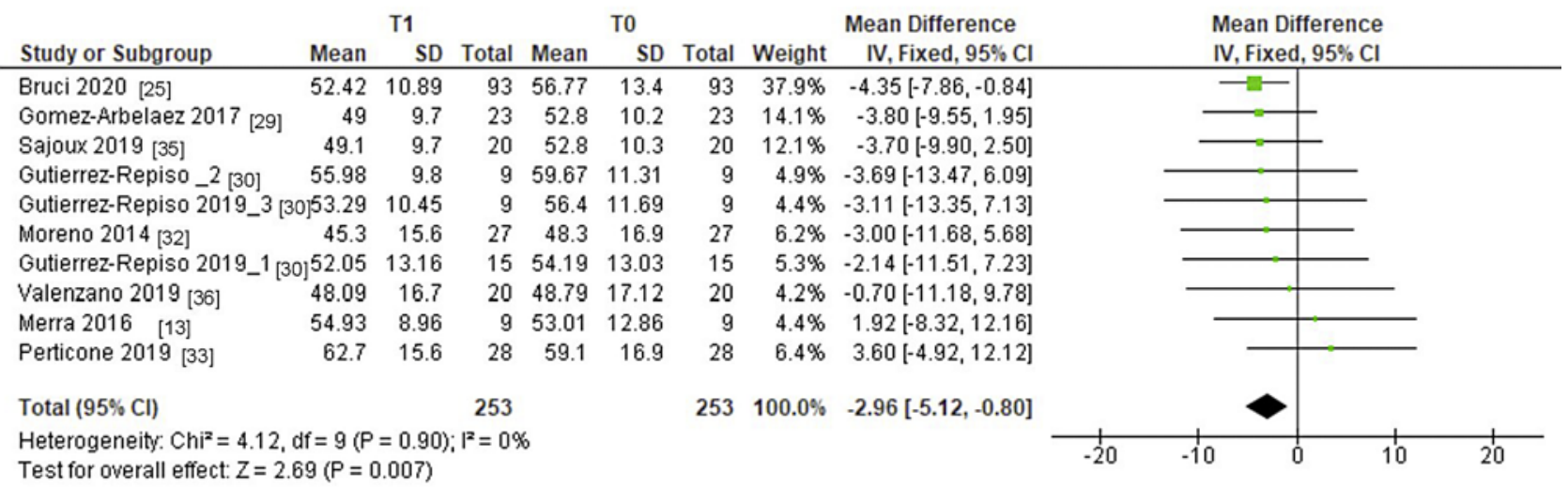

o.

\begin{tabular}{|c|c|c|c|c|c|c|c|c|c|c|c|c|}
\hline \multirow[b]{2}{*}{ Study or Subgroup } & \multicolumn{3}{|c|}{ VLCKD } & \multicolumn{3}{|c|}{ Control } & \multicolumn{3}{|c|}{ Mean Difference } & \multirow{2}{*}{\multicolumn{2}{|c|}{$\begin{array}{c}\text { Mean Difference } \\
\text { IV, Random, } 95 \% \mathrm{Cl}\end{array}$}} & \\
\hline & Mean & SD & Total & Mean & SD & Total & Weight & IV, Random, $95 \% \mathrm{Cl}$ & & & & \\
\hline Moreno 2014 [32] & -3 & 4.43 & 27 & 0 & 3.26 & 26 & $25.5 \%$ & $-3.00[-5.09,-0.91]$ & & & & \\
\hline Sajoux 2019 [35] & -3.7 & 3.16 & 20 & -1.4 & 2.11 & 59 & $26.3 \%$ & $-2.30[-3.79,-0.81]$ & & & & \\
\hline Perticone 2019 [33] & 3.6 & 4.35 & 28 & -0.8 & 3.14 & 28 & $25.6 \%$ & $4.40[2.41,6.39]$ & & & & \\
\hline Merra 2016 [13] & 1.92 & 5.22 & 9 & -3.3 & 1.44 & 9 & $22.6 \%$ & $5.22[1.68,8.76]$ & & & & \\
\hline Total $(95 \% \mathrm{Cl})$ & & & 84 & & & 122 & $100.0 \%$ & $0.94[-3.10,4.97]$ & & & & \\
\hline $\begin{array}{l}\text { Heterogeneity: } \mathrm{Tau}^{2} \\
\text { Test for overall effect }\end{array}$ & $\begin{array}{l}15.49 \\
Z=0.46\end{array}$ & $\begin{array}{l}C h i^{2}= \\
(P=0\end{array}$ & $\begin{array}{l}44.18, \\
0.65)\end{array}$ & $d f=3(P$ & $<0.00$ & $0001) ;$ & $=93 \%$ & & -50 & -25 & 25 & 50 \\
\hline
\end{tabular}

(Figure continued on next pages.)

Body Composition

A significant reduction of WC from baseline was observed after VLCKD $(-16.53 \mathrm{~cm} ; 95 \%$ CI -19.71 to -13.36 ; $I^{2}=69 \%$; Fig. 3k). Moreover, the comparison between VLCKD and other weight loss interventions of same duration showed a larger mean reduction of WC $\left(-8.33 \mathrm{~cm} ; 95 \% \mathrm{CI}-11.34\right.$ to $-5.33 ; I^{2}=92 \% ; p<0.00001$; Fig. 31). In the same direction, a significant reduction of
FM from baseline was observed after a VLCKD $(-11.12$ kg; $95 \%$ CI -14.26 to $-7.97 ; I^{2}=80 \%$ ). In addition, compared to any weight loss intervention, a VLCKD showed superiority in the reduction of FM $(-9.35 \mathrm{~kg}$; $95 \%$ CI -13.29 to $-5.41 ; I^{2}=95 \% ; p<0.00001$; Fig. $\left.3 \mathrm{~m}, \mathrm{n}\right)$. On the other hand, although the reduction in FFM after a VLCKD was $-2.96 \mathrm{~kg}$ (95\% CI -5.12 to $\left.-0.80 ; I^{2}=0 \%\right)$, this was not significantly different from the reduction in 


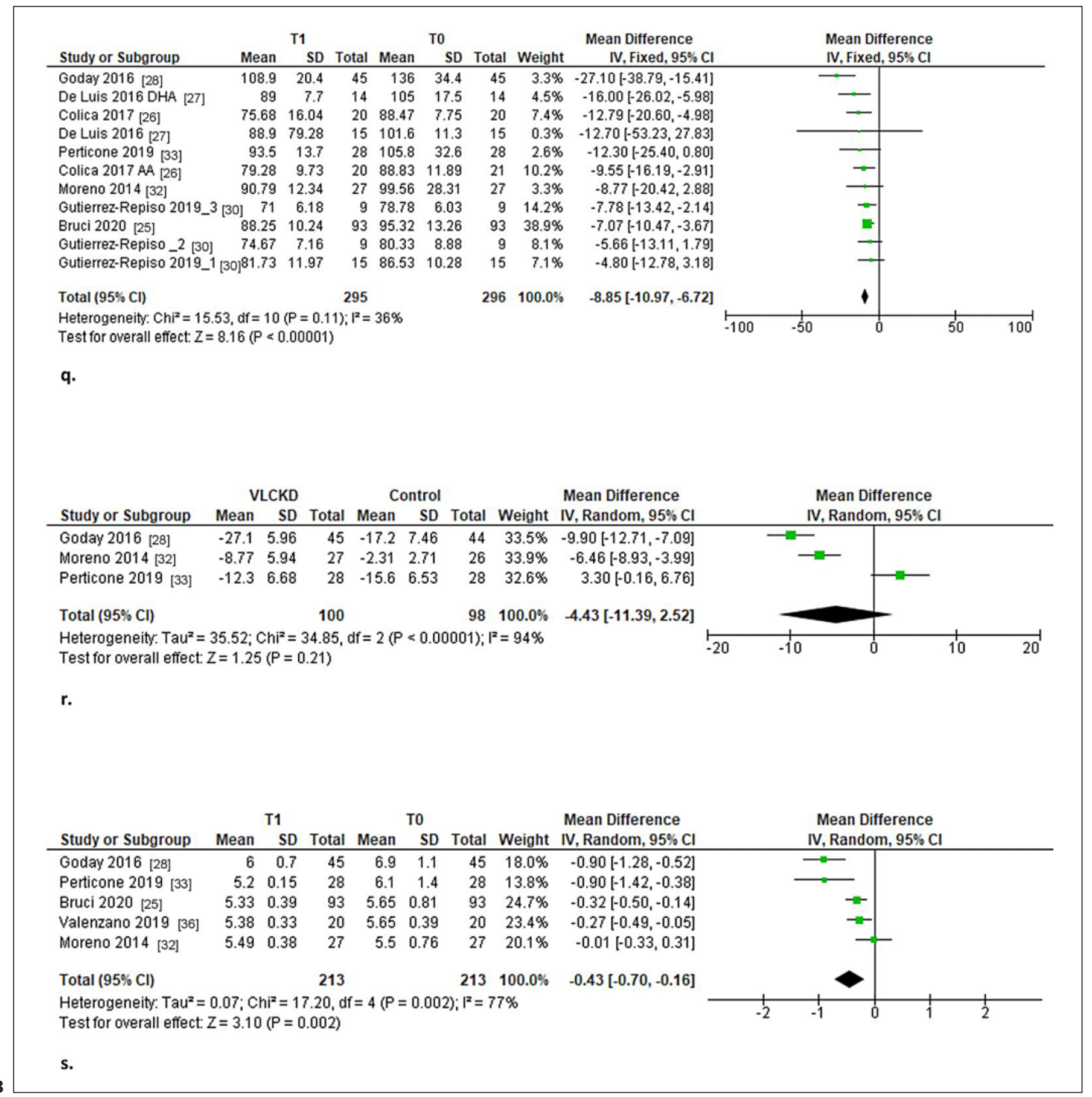

(Figure continued on next pages.)

FFM caused by other weight management interventions $(p=0.65$; Fig. 3o, p).

Glycemic Profile

In terms of fasting glycemia, a significant reduction of $-8.85 \mathrm{mg} / \mathrm{dL}$ (95\% CI -10.97 to $\left.-6.72 ; I^{2}=36 \%\right)$ was observed after a VLCKD, but this effect was not superior to that of other types of weight loss interventions $(p=0.21$; Fig. $3 \mathrm{q}, \mathrm{r})$. In the same way, a significant reduction in HbAlc $\left(-0.43 \%\right.$; $95 \%$ CI -0.70 to $\left.-0.16 ; I^{2}=77 \%\right)$ was observed after a VLCKD, without significant differences in comparison to other weight loss treatments $(p=0.14$; Fig. $3 \mathrm{~s}, \mathrm{t})$. On the other hand, a reduction in the HOMAIR index from baseline after a VLCKD $(-2.30 ; 95 \%$ CI 


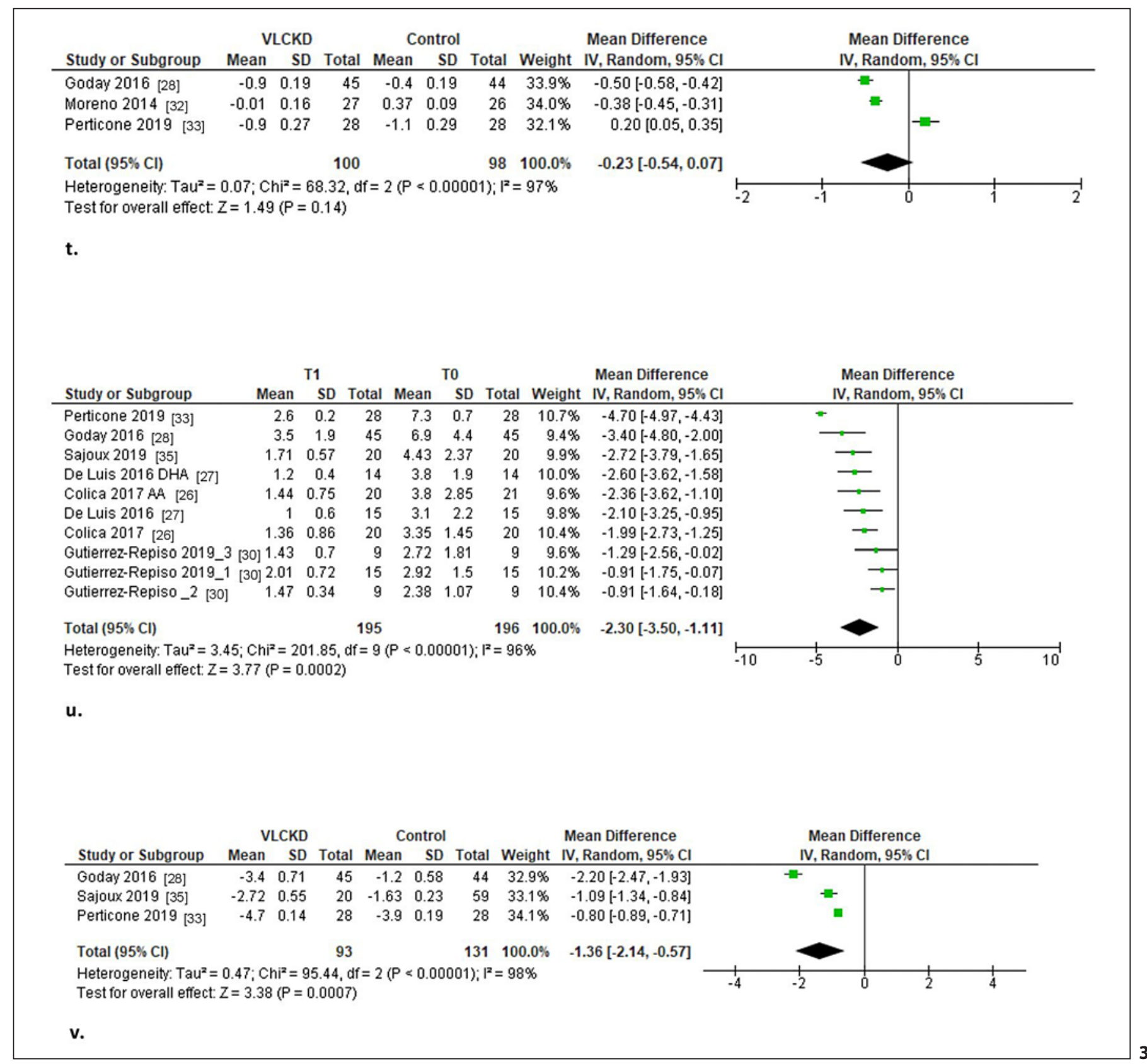

(Figure continued on next pages.)

-3.50 to $-1.11 ; I^{2}=96 \%$ ) was observed. A VLCKD had a superior effect in reducing the HOMA-IR index by -1.36 ( $95 \%$ CI -2.14 to $-0.57 ; I^{2}=98 \%$; $p<0.00001$ ), i.e., more than the other weight loss programs (Fig. $3 \mathrm{u}, \mathrm{v}$ ).

\section{Lipid Profile}

A reduction in total cholesterol after VLCKD (-17.95 $\mathrm{mg} / \mathrm{dL} ; 95 \%$ CI -23.46 to $-12.44 ; I^{2}=0 \%$ ) was observed, with a VLCKD having a larger effect in reducing total cholesterol by $-7.13 \mathrm{mg} / \mathrm{dL}$ with respect to other types of weight loss interventions ( $95 \%$ CI -9.71 to $-4.55 ; I^{2}=$ $51 \%$; $p<0.00001$; Fig. $3 \mathrm{w}, \mathrm{x})$. A significant reduction in LDL of $-9.04 \mathrm{mg} / \mathrm{dL}$ from baseline to follow-up after a VLCKD (95\% CI -13.94 to $\left.-4.15 ; I^{2}=29 \%\right)$ was observed. However, a VLCKD did not demonstrate a superior effect in terms of LDL reduction compared to other weight loss diets ( $p=0.12$; Fig. $3 y, z)$. HDL showed no change from baseline to follow-up after a VLCKD $(p=0.85)$, and interestingly when we compare the mean change in $\mathrm{HDL}$ cholesterol between a VLCKD and other weight loss in- 


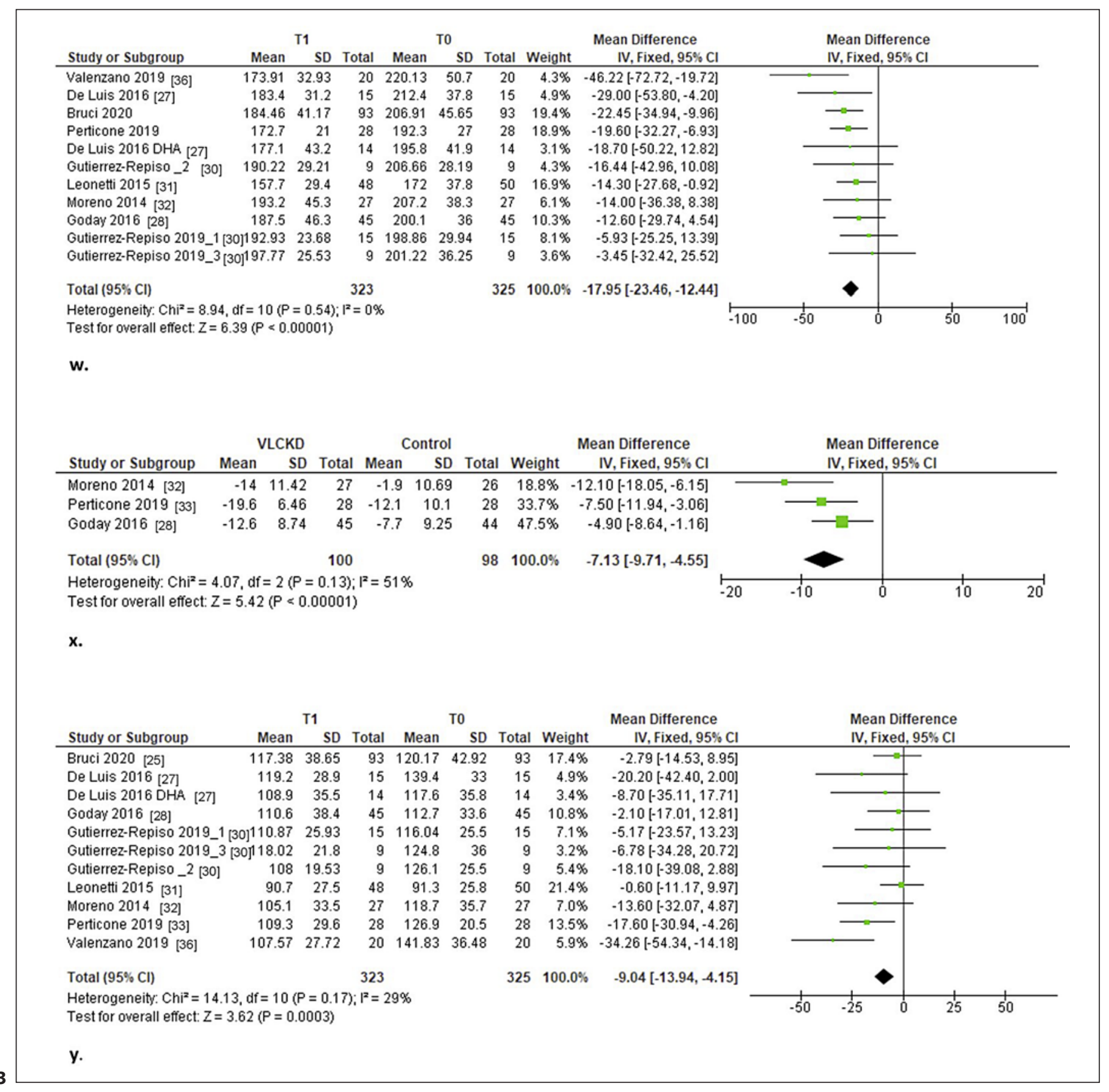

(Figure continued on next page.)

terventions we noticed a significant difference between the two $\left(+3.14 ; 95 \%\right.$ CI $0.70-5.59 ; I^{2}=84 \% ; p=0.01$; Fig. 3aa, 3bb). Finally, a significant reduction in TG $\left(-49.68 \mathrm{mg} / \mathrm{dL}: 95 \% \mathrm{CI}-58.81\right.$ to $\left.-40.55 ; I^{2}=55 \%\right)$ was observed after a VLCKD. The reduction of TG was larger after a VLCKD ( -29.90 mg/dL; 95\% CI -42.47 to -17.32; $I^{2}=89 \% ; p<0.00001$ ) compared to other diets (Fig. 3cc, dd).

VLCKD and Obesity

\section{Indications and Contraindications of VLCKD}

The main indications for the use of VLCKD in obesity are: severe obesity, treatment of obesity with bariatric indications in the preoperative period before the bariatric procedure, sarcopenic obesity, and obesity associated with hypertriglyceridemia and/or hypertension and/or type 2 diabetes and/or metabolic syndrome 


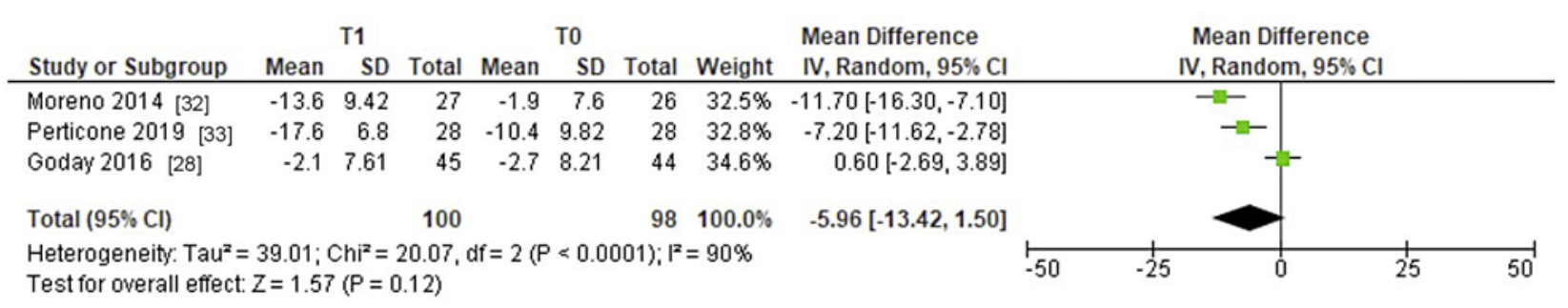

z.

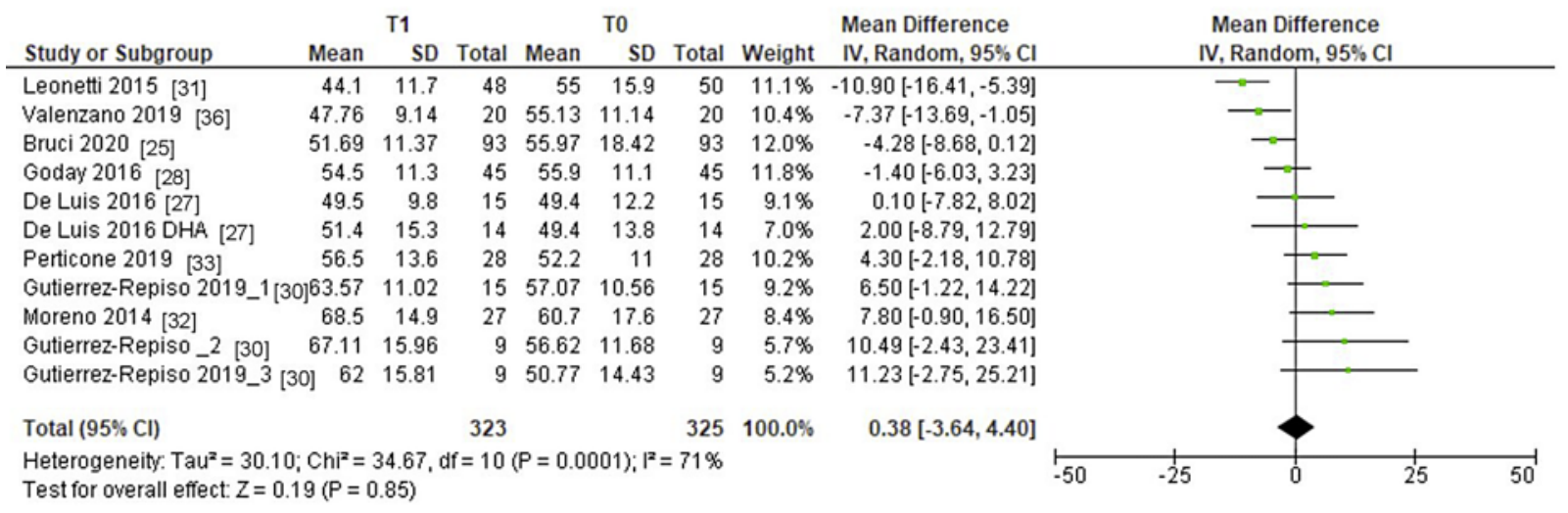

aa.

\begin{tabular}{|c|c|c|c|c|c|c|c|c|c|c|c|c|}
\hline \multirow[b]{2}{*}{ Study or Subgroup } & \multicolumn{3}{|c|}{ VLCKD } & \multicolumn{3}{|c|}{ Control } & \multicolumn{3}{|c|}{ Mean Difference } & \multirow{2}{*}{\multicolumn{2}{|c|}{$\begin{array}{c}\text { Mean Difference } \\
\text { IV, Random, } 95 \% \mathrm{Cl}\end{array}$}} & \\
\hline & Mean & SD & Total & Mean & SD & Total & Weight & IV, Random, $95 \% \mathrm{Cl}$ & & & & \\
\hline Goday 2016 [28] & -1.4 & 2.36 & 45 & -2.7 & 2.32 & 44 & $37.8 \%$ & $1.30[0.33,2.27]$ & & & 풀 & \\
\hline Perticone 2019 [33] & 4.3 & 3.31 & 28 & 1.2 & 4.12 & 28 & $32.0 \%$ & $3.10[1.14,5.06]$ & & & -1 난- & \\
\hline Moreno 2014 [32] & 7.8 & 4.44 & 27 & 2.3 & 3.78 & 26 & $30.2 \%$ & $5.50[3.28,7.72]$ & & & -미므 & \\
\hline Total $(95 \% \mathrm{Cl})$ & & & 100 & & & 98 & $100.0 \%$ & $3.14[0.70,5.59]$ & & & & \\
\hline $\begin{array}{l}\text { Heterogeneity: Tau } \\
\text { Test for overall effec }\end{array}$ & $\begin{array}{l}3.86 ; C \\
Z=2.52\end{array}$ & $\begin{array}{l}h i^{2}=1 \\
(P=\end{array}$ & $\begin{array}{l}2.61, \mathrm{df} \\
.01)\end{array}$ & $=2(\mathrm{P}$ & $=0.002$ & $2) ; 1^{2}=$ & $34 \%$ & & -20 & -10 & 10 & 20 \\
\hline
\end{tabular}

bb.

and/or NAFLD and/or obstructive sleep apnea syndrome and/or bone diseases or severe arthropathy [12, 37].

Absolute contraindications are: type 1 diabetes mellitus, latent autoimmune diabetes in adults, $\beta$-cell failure in type 2 diabetes mellitus, use of sodium/glucose cotransporter 2 (SGLT2) inhibitors (risk of euglycemic diabetic ketoacidosis), pregnancy and breastfeeding, kidney failure and severe chronic kidney disease, liver failure, hearth failure (NYHA III-IV), respiratory insufficiency, unsta- ble angina, a recent stroke or myocardial infarction $(<12$ months), cardiac arrhythmias, eating disorders and other severe mental illnesses, alcohol and substance abuse, active/severe infections, frail elderly patients, $48 \mathrm{~h}$ prior to an elective surgery or invasive procedures and a perioperative period, rare disorders such as porphyria, carnitine deficiency, carnitine palmitoyltransferase deficiency, carnitine-acylcarnitine translocase deficiency, mitochondrial fatty acid $\beta$-oxidation disorders, and pyruvate carboxylase deficiency $[12,37]$. 
Table 2. Parameters monitored during a VLCKD

\begin{tabular}{|c|c|c|c|c|}
\hline Parameters & Baseline & $\begin{array}{l}\text { During the } \\
\text { active stage }\end{array}$ & $\begin{array}{l}\text { At the end of } \\
\text { the active } \\
\text { stage }\end{array}$ & $\begin{array}{l}\text { At the end of } \\
\text { the reintro- } \\
\text { duction stage }\end{array}$ \\
\hline Weight, height, and BMI & $\mathrm{X}$ & $\mathrm{X}$ & $\mathrm{X}$ & $\mathrm{X}$ \\
\hline Body composition and hydration status (by bioelectrical impedance analysis) & $\mathrm{X}$ & $\mathrm{X}$ & $\mathrm{X}$ & $\mathrm{X}$ \\
\hline \multicolumn{5}{|l|}{ Laboratory assessment } \\
\hline Sodium, potassium, magnesium, and inorganic phosphate & $\mathrm{X}$ & $\mathrm{X}$ & $\mathrm{X}$ & $\mathrm{X}$ \\
\hline $\begin{array}{l}\text { Serum liver and kidney tests (including albumin, AST, ALT, blood urea nitrogen, } \\
\text { creatinine, } \gamma \text {-GT, and total and direct bilirubin) }\end{array}$ & $\mathrm{X}$ & $\mathrm{X}$ & $\mathrm{X}$ & $\mathrm{X}$ \\
\hline Fasting lipid profile & $\mathrm{X}$ & & & $\mathrm{X}$ \\
\hline $25(\mathrm{OH}) \mathrm{D}$, calcium & $\mathrm{X}$ & & & $\mathrm{X}$ \\
\hline Glucose and insulin & $\mathrm{X}$ & & & $\mathrm{X}$ \\
\hline
\end{tabular}

\section{Side Effects of VLCKD and Their Medical Management}

The VLCKD is a nutritional approach that has significant beneficial effects on anthropometric and metabolic parameters and on body composition. To prevent side effects and to assess the efficacy of VLCKD, it is suggested to carry out periodic monitoring through a physical examination and laboratory assessment as reported in Table 2.

\section{Common Side Effects}

Dehydration-Related Disorders

Ketone bodies usually produced during the active stage of a VLCKD are passed via frequent and increased urination. This can lead to dehydration and a loss of electrolytes [38]. Dehydration-related disorders are mostly represented by a dry mouth, headache, dizziness/orthostatic hypotension, lethargy, and visual disturbances [8]. Thus, it is advisable to recommend a proper water intake (at least $2 \mathrm{~L}$ daily), in particular during the ketogenic state. Since liquid formulations of the analgesic could contain sugar, it is preferable to take analgesics as pills to relieve headache. The most common electrolyte alterations are represented by hyponatremia and hypomagnesemia, which are potentially a link not only to dehydration but also to the scarce intake of these micronutrients. Subjects with a normal sodium equilibrium experience natriuresis for a few days, usually from day 2 to day 6 , with the peak natriuresis occurring on day 4 , and after that they spontaneously recover. Mild kaliuresis occurs from day 5 to day 7 of the fast, after which there is a return to a positive potassium balance [39]. If there are no contraindications, an increased salt intake (2-3 g/day, except in hypertension, chronic kidney disease, or chronic heart failure) should be recommended to subjects with hypotension-related symptoms. Muscle cramps and sleep disturbances can be attenuated by the administration of magnesium.

\section{Transient Hypoglycemia}

Transient hypoglycemia could occur in the initial period of the active stage but also during the initial step-wise increase in caloric intake in the nonfasting protocol [38]. The acute calorie restriction along with the properties of ketone bodies to stimulate insulin secretion may result in transient hypoglycemia [40]. Furthermore, the decrease in FM consequent to weight loss results in decreased oxidation of lipids and increased oxidation of glucose. This net effect of the shift in oxidation of fuels improves glucose metabolism through the reduction of insulin resistance [41].

The decrease in hepatic triacylglycerol as a consequence of the reduced carbohydrate intake usually improves hepatic insulin resistance and thus reduces hepatic glucose production [42]. If hypoglycemia occurs, it is usually clinically mild and not associated with hypoglycemic symptoms. In the rare case where the blood glucose level is $<40 \mathrm{mg} / \mathrm{dL}$ and hypoglycemia is symptomatic, carbohydrate-containing beverages such as orange juice are recommended. 
Halitosis

Subjects often report bad breath with a fruity smell once they reach full ketosis. This is caused by the increased ketone levels and in particular by an increase of acetone [43]. Chewing sugar-free gum and/or candy could be a strategy to manage this discomfort.

\section{Gastrointestinal Side Effects}

Nausea/vomiting, diarrhea, and constipation are the most common gastrointestinal side effects of a VLCKD and they can often lead to VLCKD discontinuation [38]. Diarrhea is usually easily manageable with short-term antidiarrhea medication. Diarrhea could be due to defective absorption and intolerance of fat. The high content of lipids can slow gastric emptying, favoring gastroesophageal reflux disease, nausea, and vomiting. Relief of this symptom could come from small and frequent meals, the sporadic use of gastrointestinal drugs such as antiemetics, gastrointestinal tract regulators, and antiacids. A decreased in water intake, fiber, and/or the volume of food can cause the onset to constipation [44]. If this is the case, it is recommended to increase the water and fiber intake and, in severe cases, the administration of low-calorie bulk laxatives and/or intermittent enemas. If subjects refer preexisting constipation, diverticular disease or hemorrhoids, it is recommended to prescribe extra dietary fiber (psyllium at $3.5 \mathrm{~g}$ twice daily) from the beginning of the nutritional protocol [45].

\section{Hyperuricemia}

Hyperuricemia could be detected in subjects on a VLCKD. Indeed, plasma uric acid levels usually increase if the diet is low in carbohydrates and they follow a biphasic course, with a peak in 1-2 weeks and then a decrease to baseline [46]. Special attention must be paid to patients with a prior history of gout because they could be more prone to developing exacerbations and they could benefit from allopurinol therapy. However, acute gouty arthritis has been reported in $<1 \%$ of subjects on a VLCKD [47].

\section{Lipid Profile Changes}

A decrease in plasma TG, increased LDL cholesterol, and a neutral effect on HDL cholesterol are usually observed. The increase in LDL cholesterol is mostly due to a high lipid intake [12], but it is transient and values usually return to normal levels at the end of the VLCKD [48]. If the LDL level does not spontaneously improve after returning to a normal diet, the use of cholesterol-reducing medications should be taken into account.

\section{Rare Side Effects}

Hypoproteinemia

The glucogenogenic consumption due to carbohydrate restriction could result in hypoproteinemia [49]. Increasing the protein intake from 1 to $1.5 \mathrm{~g} / \mathrm{kg} /$ day could be a strategy to manage this side effect.

\section{Hypocalcemia and Bone Damage}

Although no studies have been carried out in subjects on a VLCKD with the aim of investigating calcium metabolism, it could be hypothesized that a nutritional protocol rich in acid-ash protein could result in an excessive calcium loss because of its acidogenic content because calcium works as a buffer in the skeleton through the active resorption of bone [36]. Calciuria is positively related to net acid excretion and it is not compensated by increasing intestinal calcium absorption [50]. However, calciuria seems to be not so excessive as to increase the risk of developing osteoporosis [50]. Furthermore, in subjects on a VLCKD who are supplemented with a calcium intake $(1,200 \mathrm{mg} /$ day $)$, the calcium balance has been reported to be positive [51]. However, since studies mostly on the long-term fracture risk are lacking, it is advisable to recommend an adequate intake of calcium and to treat vitamin $\mathrm{D}$ deficiency in order to restore vitamin D levels to normal during a VLCKD. Particular attention should be paid to subjects with osteopenia/osteoporosis who are at a high risk of developing fractures.

\section{Urolithiasis}

Chronic acidosis, dehydration, and fat malabsorption occurring during a VLCKD could predispose to urolithiasis $[52,53]$. The stones mostly consist of uric acid, calcium oxalate, or a mixture of calcium oxalate and calcium phosphate/uric acid $[52,53]$. This disorder is more common if there are risk factors such as a young age, a family history of kidney stones, and a urine $\mathrm{Ca} / \mathrm{Cr}$ ratio $>0.2$ [52]. An adequate water intake (at least $2 \mathrm{~L}$ daily) along with the administration of oral potassium citrate is recommended to alkalinize urine, mostly in subjects with risk factors.

\section{Gallstones}

Weight loss during a VLCKD could increase the risk of developing gallstones, as previously reported after rapid weight loss, either via a VLCD or via bariatric surgery [54]. Supersaturation of bile with cholesterol, leading to cholesterol crystallization and stone formation, and insufficient gallbladder emptying due to impaired motility are the 2 most commonly suggested mechanisms for gall- 
stone formation [55]. However, a fat intake of at least 7-10 g daily could be the threshold for maintaining an efficient gallbladder emptying [56].

\section{Hair Loss}

A significant negative nitrogen balance could account for hair loss occurring during a VLCKD. Indeed, when the mobilization of body protein plus dietary protein is not able to meet the requirements, the low priority of hair growth for the available protein is responsible for the telogen effluvium [57]. However, the hair loss is transient and hair grows as well as weight stabilizes. An increased protein intake during a VLCKD in order to equilibrate the nitrogen balance contributes to the prevention of hair loss.

\section{Discussion}

The aim of this paper was to provide benchmark data on the effects of VLCKD in terms of short- and intermediate-term weight loss and changes/improvement in body composition patterns and glycemic and lipid profiles. The systematic review and meta-analysis included 15 studies who were objectively judged to be of a high quality and yielded 4 main findings. The first finding was that a VLCKD is associated with a significant reduction in body weight and BMI at 1, 2, 4-6, 12, and 24 months, it and appears to be associated with larger weight loss rates compared to other diets with a different energy content (i.e., LCD and VLCD) of the same duration. The second finding is that a VLCKD is associated with a significant reduction of WC (an expression of central fat) and FM, and this reduction is significantly larger than those achieved with other weight loss interventions of the same duration. However, the reduction in FFM after a VLCKD was not significantly different from the reduction in FFM caused by other weight management interventions, meaning that a VLCKD does not have a better effect in conserving the lean mass as has been speculated by some authors. The third finding is in terms of glycemia and HbA1c, with a significant reduction detected after a VLCKD, without superiority in comparison to other types of weight loss interventions. On the other hand, a VLCKD was associated with a reduction of the HOMAIR index and an improvement in insulin sensitivity, and this effect was superior to that of other weight loss programs. The fourth finding is that a VLCKD was associated with a reduction in total cholesterol and it was noted to have a major effect in reducing the total cholesterol compared to other weight loss programs. In the same direction, a VLCKD led to a significant reduction in LDL from baseline to follow-up after VLCKD; however it did not demonstrate a superior effect compared to other weight loss diets in terms of LDL reduction. On the other hand, no change was detected in HDL from baseline to follow-up after a VLCKD, and interestingly no differences were detected when we comparing the mean change in HDL cholesterol between a VLCKD and other weight loss interventions. Finally, a significant reduction in TG from baseline was associated with a VLCKD and it was shown to be superior compared to other diets.

The main findings of our study should be considered robust, as we strictly adhered to PRISMA guidelines, and this methodological robustness lends weight to the validity of the conclusions. The studies included in this document were extremely well designed, including both randomized samples and appropriate control groups. Finally, the instruments used in all of the studies to assess the anthropometric and metabolic outcomes have been amply validated and acknowledged in both clinical and research settings.

One major concern regards the side effects of VLCKD. Indeed, few studies have been carried out in subjects with obesity and no study has been set up to specifically assess the side effects. Nevertheless, the included studies that did report side effects associated with ketogenic diets found no meaningful common side effects. They are mostly: dehydration-related disorders, transient hypoglycemia, halitosis, gastrointestinal disorders, hyperuricemia, and lipid profile changes. They are reported to be clinically mild and often recovery occurs spontaneously. Side effects could be prevented and managed by adhering to appropriate indications and contraindications for VLCKD, by following well-organized and standardized protocols, and by performing adequate clinical and laboratory monitoring; for instance, close lipid profile monitoring is important since VLCKD are high-fat low-carbohydrate adequate protein diets that may create a subsequent spike in the plasma levels of total cholesterol and TG, which could, in turn, raise the risk for cardiovascular diseases. Therefore, VLCKD should be carried out under the supervision of a health professional.

\section{Conclusions and Recommendations}

After a careful systematic review and meta-analysis of the current evidence, and considering the potential side effects, VLCKD can be recommended as an effective di- 
etary treatment for individuals with obesity, in particular for patients with severe obesity and/or comorbidities (joint diseases, preoperative period of bariatric surgery, and cardiovascular and metabolic diseases) who need immediate and substantial weight loss. Therefore, VLCKD can be prescribed targeting a specific population of patients with obesity after consideration of the potential contraindications and under medical surveillance. However, it is important to personalize the diet, based on the patient's preferences, allowing food choices within the VLCKD protocol. After achievement of the weight target with VLCKD, implementation of long-term lifestyle strategies (physical activity and nutritional counselling) is strongly recommended to reduce the risk of weight regain in the long term.

\section{Acknowledgement}

We would like to thank Mr. Euan Woodward the Executive Director of the European Association for the Study of Obesity (EASO) for his kind assessment.

\section{Statement of Ethics}

Ethical approval is not required because this paper includes information freely available in the public domain and the analysis of data sets, either open source or obtained from other researchers, where the data are properly anonymized and informed consent was obtained at the time of the original data collection.

\section{Conflict of Interest Statement}

The authors have no conflict of interests to declare.

\section{Funding Sources}

This document was written under the auspices of EASO, which covered the article processing fees.

\section{Author Contributions}

G.M., M.E.G., and L.B.: conceptualization. A.C.: methodology. V.Y. and M.H.: validation. M.E.G.: formal analysis. G.M.: investigation and resources. M.H.: data curation. G.M. and M.E.G.: writing and original draft preparation. A.C., V.Y., M.H., and L.B.: review and editing. L.B.: visualization and supervision.

\section{References}

1 The European Association for the Study of Obesity. Obesity statistics. Available from: https://easo.org/media-portal/statistics/. 2020.

2 Jastreboff AM, Kotz CM, Kahan S, Kelly AS, Heymsfield SB. Obesity as a Disease: The Obesity Society 2018 Position Statement. Obesity (Silver Spring). 2019 Jan;27(1):7-9.

3 De Lorenzo A, Gratteri S, Gualtieri P, Cammarano A, Bertucci P, Di Renzo L. Why primary obesity is a disease? J Transl Med. 2019 May;17(1):169.

4 Brehm BJ, Seeley RJ, Daniels SR, D’Alessio DA. A randomized trial comparing a very low carbohydrate diet and a calorie-restricted low fat diet on body weight and cardiovascular risk factors in healthy women. J Clin Endocrinol Metab. 2003 Apr;88(4):1617-23.

5 Siraj ES, Williams KJ. Another Agent for Obesity-Will This Time Be Different? N Engl J Med. 2015 Jul;373(1):82-3.

6 Patel DK, Stanford FC. Safety and tolerability of new-generation anti-obesity medications: a narrative review. Postgrad Med. 2018 Mar; 130(2):173-82.

7 Fried M, Yumuk V, Oppert JM, Scopinaro N, Torres AJ, Weiner R, et al.; European Association for the Study of Obesity; International Federation for the Surgery of Obesity - European Chapter. Interdisciplinary European Guidelines on metabolic and bariatric surgery. Obes Facts. 2013;6(5):449-68.
8 Muscogiuri G, Barrea L, Laudisio D, Pugliese G, Salzano C, Savastano S, et al. The management of very low-calorie ketogenic diet in obesity outpatient clinic: a practical guide. J Transl Med. 2019 Oct;17(1):356.

9 Westman EC, Feinman RD, Mavropoulos JC, Vernon MC, Volek JS, Wortman JA, et al. Low-carbohydrate nutrition and metabolism. Am J Clin Nutr. 2007 Aug;86(2):276-84.

10 Moreno B, Crujeiras AB, Bellido D, Sajoux I, Casanueva FF. Obesity treatment by very lowcalorie-ketogenic diet at two years: reduction in visceral fat and on the burden of disease. Endocrine. 2016 Dec;54(3):681-90.

11 Gomez-Arbelaez D, Crujeiras AB, Castro AI, Martinez-Olmos MA, Canton A, OrdoñezMayan L, et al. Resting metabolic rate of obese patients under very low calorie ketogenic diet. Nutr Metab (Lond). 2018 Feb;15(1):18.

12 Caprio M, Infante M, Moriconi E, Armani A, Fabbri A, Mantovani G, et al.; Cardiovascular Endocrinology Club of the Italian Society of Endocrinology. Very-low-calorie ketogenic diet (VLCKD) in the management of metabolic diseases: systematic review and consensus statement from the Italian Society of Endocrinology (SIE). J Endocrinol Invest. 2019 Nov;42(11):1365-86.

13 Merra G, Miranda R, Barrucco S, Gualtieri P, Mazza M, Moriconi E, et al. Very-low-calorie ketogenic diet with aminoacid supplement versus very low restricted-calorie diet for pre- serving muscle mass during weight loss: a pilot double-blind study. Eur Rev Med Pharmacol Sci. 2016 Jul;20(12):2613-21.

14 Richardson WS, Wilson MC, Nishikawa J, Hayward RS. The well-built clinical question: a key to evidence-based decisions. ACP J Club. 1995;123(3):A12-3.

15 Liberati A, Altman DG, Tetzlaff J, Mulrow C, Gøtzsche PC, Ioannidis JP, et al. The PRISMA statement for reporting systematic reviews and meta-analyses of studies that evaluate health care interventions: explanation and elaboration. Ann Intern Med. 2009 Aug;151(4):W65-94.

16 Kreidieh D, Itani L, El Kassas G, El Masri D, Calugi S, Dalle Grave R, et al. Long-term Lifestyle-modification Programs for Overweight and Obesity Management in the Arab States: Systematic Review and Meta-analysis. Curr Diabetes Rev. 2018;14(6):550-8.

17 Stang A. Critical evaluation of the NewcastleOttawa scale for the assessment of the quality of nonrandomized studies in meta-analyses. Eur J Epidemiol. 2010 Sep;25(9):603-5.

18 Wang Y, Ji J, Liu YJ, Deng X, He QQ. Passive smoking and risk of type 2 diabetes: a metaanalysis of prospective cohort studies. PLoS One. 2013 Jul;8(7):e69915.

19 Clark HD, Wells GA, Huët C, McAlister FA, Salmi LR, Fergusson D, et al. Assessing the quality of randomized trials: reliability of the Jadad scale. Control Clin Trials. 1999 Oct; 20(5):448-52. 
20 Kiehna EN, Starke RM, Pouratian N, Dumont AS. Standards for reporting randomized controlled trials in neurosurgery. J Neurosurg. 2011 Feb;114(2):280-5.

21 Chess LE, Gagnier J. Risk of bias of randomized controlled trials published in orthopaedic journals. BMC Med Res Methodol. 2013 Jun;13(1):76.

22 Higgins JP, Chandler J, Cumpston M, Li T, Page MJ, Welch VA, editors. Cochrane handbook for systematic reviews of interventions, version 6.0 (updated July 2019). 2019. Available from: www.training.cochrane.org/handbook.

23 Cochrane Software Review Manager (RevMan). Version 5.3 [software]. Copenhagen: The Nordic Cochrane Centre TCC, 2014.

24 Albanese A, Prevedello L, Markovich M, Busetto L, Vettor R, Foletto M. Pre-operative Very Low Calorie Ketogenic Diet (VLCKD) vs. Very Low Calorie Diet (VLCD): surgical Impact. Obes Surg. 2019 Jan;29(1):292-6.

25 Bruci A, Tuccinardi D, Tozzi R, Balena A, Santucci S, Frontani R, et al. Very Low-Calorie Ketogenic Diet: A Safe and Effective Tool for Weight Loss in Patients With Obesity and Mild Kidney Failure. Nutrients. 2020 Jan; 12(2):E333.

26 Colica C, Merra G, Gasbarrini A, De Lorenzo A, Cioccoloni G, Gualtieri P, et al. Efficacy and safety of very-low-calorie ketogenic diet: a double blind randomized crossover study. Eur Rev Med Pharmacol Sci. 2017 May;21(9): 2274-89.

27 de Luis D, Domingo JC, Izaola O, Casanueva FF, Bellido D, Sajoux I. Effect of DHA supplementation in a very low-calorie ketogenic diet in the treatment of obesity: a randomized clinical trial. Endocrine. 2016 Oct;54(1):11122.

28 Goday A, Bellido D, Sajoux I, Crujeiras AB, Burguera B, García-Luna PP, et al. Short-term safety, tolerability and efficacy of a very lowcalorie-ketogenic diet interventional weight loss program versus hypocaloric diet in $\mathrm{pa}$ tients with type 2 diabetes mellitus. Nutr Diabetes. 2016 Sep;6(9):e230.

29 Gomez-Arbelaez D, Bellido D, Castro AI, Ordoñez-Mayan L, Carreira J, Galban C, et al. Body Composition Changes After Very-LowCalorie Ketogenic Diet in Obesity Evaluated by 3 Standardized Methods. J Clin Endocrinol Metab. 2017 Feb;102(2):488-98.

30 Gutiérrez-Repiso C, Hernández-García C, García-Almeida JM, Bellido D, MartínNúñez GM, Sánchez-Alcoholado L, et al. Effect of Synbiotic Supplementation in a VeryLow-Calorie Ketogenic Diet on Weight Loss Achievement and Gut Microbiota: A Randomized Controlled Pilot Study. Mol Nutr Food Res. 2019 Oct;63(19):e1900167.
31 Leonetti F, Campanile FC, Coccia F, Capoccia D, Alessandroni L, Puzziello A, et al. Very low-carbohydrate ketogenic diet before bariatric surgery: prospective evaluation of a sequential diet. Obes Surg. 2015 Jan;25(1):6471.

32 Moreno B, Bellido D, Sajoux I, Goday A, Saavedra $D$, Crujeiras $A B$, et al. Comparison of a very low-calorie-ketogenic diet with a standard low-calorie diet in the treatment of obesity. Endocrine. 2014 Dec;47(3):793-805.

33 Perticone M, Maio R, Sciacqua A, Suraci E, Pinto A, Pujia R, et al. Ketogenic Diet-Induced Weight Loss is Associated with an Increase in Vitamin D Levels in Obese Adults. Molecules. 2019 Jul;24(13):E2499.

34 Rubini A, Bosco G, Lodi A, Cenci L, Parmagnani A, Grimaldi K, et al. Effects of Twenty Days of the Ketogenic Diet on Metabolic and Respiratory Parameters in Healthy Subjects. Lung. 2015 Dec;193(6):939-45.

35 Sajoux I, Lorenzo PM, Gomez-Arbelaez D, Zulet MA, Abete I, Castro AI, et al. Effect of a Very-Low-Calorie Ketogenic Diet on Circulating Myokine Levels Compared with the Effect of Bariatric Surgery or a Low-Calorie Diet in Patients with Obesity. Nutrients. 2019 Oct; 11(10):E2368.

36 Valenzano A, Polito R, Trimigno V, Di Palma A, Moscatelli F, Corso G, et al. Effects of Very Low Calorie Ketogenic Diet on the Orexinergic System, Visceral Adipose Tissue, and ROS Production. Antioxidants (Basel). 2019 Dec; 8(12):643

37 Associazione Italiana di Dietetica e Nutrizione Clinica. Attualità in dietetica e nutrizione clinica. Available from: https://www.fondazioneadi.com/wp-content/uploads/paper/2018/01/ADI-ATTUALITA-N.-2_2014. pdf.

38 Kang HC, Chung DE, Kim DW, Kim HD. Early- and late-onset complications of the ketogenic diet for intractable epilepsy. Epilepsia. 2004 Sep;45(9):1116-23.

39 Boulter PR, Hoffman RS, Arky RA. Pattern of sodium excretion accompanying starvation. Metabolism. 1973 May;22(5):675-83.

40 Balasse EO, Ooms HA, Lambilliotte JP. Evidence for a stimulatory effect of ketone bodies on insulin secretion in man. Horm Metab Res. 1970 Nov;2(6):371-2.

41 Franssila-Kallunki A, Rissanen A, Ekstrand A, Ollus A, Groop L. Weight loss by very-lowcalorie diets: effects on substrate oxidation, energy expenditure, and insulin sensitivity in obese subjects. Am J Clin Nutr. 1992 Jul;56(1 Suppl):247S-8S.

42 Lim EL, Hollingsworth KG, Aribisala BS, Chen MJ, Mathers JC, Taylor R. Reversal of type 2 diabetes: normalisation of beta cell function in association with decreased pancreas and liver triacylglycerol. Diabetologia. 2011 Oct;54(10):2506-14.
43 Musa-Veloso K, Likhodii SS, Cunnane SC. Breath acetone is a reliable indicator of ketosis in adults consuming ketogenic meals. Am J Clin Nutr. 2002 Jul;76(1):65-70.

44 Wheless JW. The ketogenic diet. In: Swaiman KF, editor. Pediatric neurology: principles and practice. Maryland Heights: Mosby; 1999.

45 Leeds AR. Formula food-reducing diets:A new evidence-based addition to the weight management tool box. Nutr Bull. 2014 Sep 39(3):238-46.

46 Atkinson RL. Low and very low calorie diets. Med Clin North Am. 1989 Jan;73(1):203-15.

47 Palgi A, Read JL, Greenberg I, Hoefer MA, Bistrian BR, Blackburn GL. Multidisciplinary treatment of obesity with a protein-sparing modified fast: results in 668 outpatients. Am J Public Health. 1985 Oct;75(10):1190-4.

48 Swink TD, Vining EP, Freeman JM. The ketogenic diet: 1997. Adv Pediatr. 1997;44:297329

49 Ballaban-Gil K, Callahan C, O’Dell C, Pappo M, Moshé S, Shinnar S. Complications of the ketogenic diet. Epilepsia. 1998 Jul;39(7):7448.

50 Fenton TR, Lyon AW, Eliasziw M, Tough SC, Hanley DA. Meta-analysis of the effect of the acid-ash hypothesis of osteoporosis on calcium balance. J Bone Miner Res. 2009 Nov; 24(11):1835-40.

51 Davie MW, Abraham RR, Hewins B, Wynn $\mathrm{V}$. Changes in bone and muscle constituents during dieting for obesity. Clin Sci (Lond). 1986 Mar;70(3):285-93.

52 Furth SL, Casey JC, Pyzik PL, Neu AM, Docimo SG, Vining EP, et al. Risk factors for urolithiasis in children on the ketogenic diet. Pediatr Nephrol. 2000 Nov; 15(1-2):125-8.

53 Kielb S, Koo HP, Bloom DA, Faerber GJ. Nephrolithiasis associated with the ketogenic diet. J Urol. 2000 Aug;164(2):464-6.

54 Everhart JE. Contributions of obesity and weight loss to gallstone disease. Ann Intern Med. 1993 Nov;119(10):1029-35

55 Festi D, Colecchia A, Larocca A, Villanova N Mazzella G, Petroni ML, et al. Review: low caloric intake and gall-bladder motor function. Aliment Pharmacol Ther. 2000 May; 14 Suppl $2: 51-3$

56 Johansson K, Sundström J, Marcus C, Hemmingsson E, Neovius M. Risk of symptomatic gallstones and cholecystectomy after a verylow-calorie diet or low-calorie diet in a commercial weight loss program: 1-year matched cohort study. Int J Obes. 2014 Feb;38(2):27984.

57 Blackburn GL, Bistrian BR, Hoag C. Letter: hair loss with rapid weight loss. JAMA. 1976 Jul;236(3):252. 